\title{
3D printing of graphene-based polymeric nanocomposites for biomedical applications
}

\author{
Magda Silva ${ }^{1,2,3 \dagger}$, Isabel S. Pinho ${ }^{1,2,3 \dagger}$, José A. Covas $^{3}$, Natália M. Alves ${ }^{1,2^{*}}$ and Maria C. Paiva ${ }^{3^{*}}$ (D)
}

\begin{abstract}
Additive manufacturing techniques established a new paradigm in the manufacture of composite materials providing a simple solution to build complex, custom designed shapes. In the biomedical field, 3D printing enabled the production of scaffolds with patient-specific requirements, controlling product architecture and microstructure, and have been proposed to regenerate a variety of tissues such as bone, cartilage, or the nervous system. Polymers reinforced with graphene or graphene derivatives have demonstrated potential interest for applications that require electrical and mechanical properties as well as enhanced cell response, presenting increasing interest for applications in the biomedical field. The present review focuses on graphene-based polymer nanocomposites developed for additive manufacturing fabrication, provides an overview of the manufacturing techniques available to reach the different biomedical applications, and summarizes relevant results obtained with 3D printed graphene/ polymer scaffolds and biosensors.
\end{abstract}

Keywords: Additive manufacturing, 3D printing, Graphene-based nanocomposites, Biomedical applications

\section{Introduction}

Graphene, a one-atom thick two-dimensional carbon material, has remarkable mechanical, thermal, electrical, and physicochemical properties. However, practical applications of graphene are still limited. As a nanofiller for polymer-based composites, graphene can significantly improve the properties at low incorporation levels. These composites are potentially suitable for a wide range of applications in electronics, energy storage, thermal engineering, automotive and healthcare [1].

The biomedical device industry is vast and expected to be valued at 409.5 billion dollars by 2023 [2]. Graphenebased composites are mostly used for the fabrication of

\footnotetext{
* Correspondence: nalves@i3bs.uminho.pt; mcpaiva@dep.uminho.pt ${ }^{+}$Magda Silva and Isabel S. Pinho contributed equally to this work. '3B's Research Group, I3Bs - Research Institute on Biomaterials, Biodegradables and Biomimetics University of Minho, Headquarters of the European Institute of Excellence on Tissue Engineering and Regenerative Medicine, AvePark, 4805-017 Barco, Guimarães, Portugal

${ }^{3}$ Institute for Polymers and Composites, Campus of Azurém, University of Minho, 4804-533 Guimarães, Portugal

Full list of author information is available at the end of the article
}

3D structures such as scaffolds for tissue engineering [3] and also for biosensing $[4,5]$. Suitable scaffolds have been developed using conventional fabrication methods such as solvent casting, freeze-drying and salt leaching [6-8]. However, control over the scaffold geometry is limited [3] and the production of multifunctional, multimaterial scaffold structures is challenging [2]. The recent advancements in additive manufacturing brought about new and exciting possibilities for the fabrication of complex architectures for biomedical applications [3].

Additive manufacturing (AM), also known as 3D printing or rapid prototyping, denotes a group of techniques where a computer-aided design (CAD) model is converted into a 3D object, which is successively built layer-by-layer. This contrasts obviously with the conventional formative (e.g., injection moulding, casting) and subtractive methods (e.g, turning, drilling). AM techniques can fabricate complex structures (eventually not possible to obtain by the other methods) in a relatively short time and with low cost, since they do not require a 
shaping mold and generate minimal waste. These unique features induced revolutionary applications of AM in healthcare, aerospace, automotive, electronics and civil construction $[2,9,10]$. In the medical/biomedical field, AM has been applied in tissue engineering to design personalized scaffolds or artificial tissues and organs for transplants, drug delivery systems, probes and tools to detect specific medical parameters, orthoses, prostheses and implants, anatomical models and medical instruments for diagnostics and surgery $[11,12]$.

It is estimated that biomedical applications share about $11 \%$ of the AM technology market and this percentage is steadily increasing [13]. Indeed, AM is suited to manufacture small quantities of customized prototypes or products, which is particularly useful as patientcustomized products are frequently required [14]. The availability of $3 \mathrm{D}$ printed prototypes of a patient unique anatomy can improve surgery planning, implant design, and provide specialized medical procedure training. The ability to 3D print not only biomaterials, but also living cells and/or other biological components (e.g. distinct proteins, growth factors), known as bioprinting, enables the creation of biological constructs that can regenerate or augment lost/damaged tissues and organs [2].

The use of polymer nanocomposites combined with the versatility of AM provide great potential to meet the demands of a wide range of clinical needs $[2,3]$ by creating personalized implants, organ printing, drug delivery devices as well as regenerative scaffolds. In particular, the incorporation of graphene and its derivatives can improve the dimensional accuracy as well as the mechanical, electrical and biological properties of novel biomedical devices [2].

This review discusses the recent advances of using AM techniques and graphene-based polymer nanocomposites to manufacture biomedical products and devices, with emphasis on scaffolds and biosensors. The main 3D printing techniques used with polymers are first introduced. Then, the main preparation methods of graphene-based polymer nanocomposites are reviewed. Finally, representative examples of 3D printed graphenebased scaffolds and biosensors are discussed.

\section{D printing techniques for polymers}

AM techniques use computer files describing the 3D geometry of the part or prototype to be produced, to successively build a series of horizontal 2D layers in the vertical direction, usually from the bottom to the top. The techniques vary in terms of the material deposition procedure, the physical form of the material (liquid, solid or powder-based) and the nature of the material (e.g., thermoplastics, thermosets, nanocomposites, fiber composites). The length-scale, dimensional accuracy and surface finish of the printed object will also depend on the
AM technique utilized. Moreover, some techniques are better suited to industrial production than others [13, 15].

Generally, the printing process involves the following steps (see Fig. 1):

a) Definition of the geometry and dimensions of the 3D structure to be manufactured, using computer-aided design (CAD) software;

b) Conversion of the design into a digital approximation (using triangulations) as a Standard Tessellation Language (STL) file format;

c) Slicing of the 3D model into layers of specified thickness, using dedicated software;

d) Use of G-code commands (often via a user-friendly interface) to define how the printer will work during the printing sequence. For example, the in-fill density will determine the porosity of a part;

e) Transfer of the files to the actual 3D printer;

f) Layer-by-layer manufacturing of the part, eventually followed by post-processing operations (such as removing support material, sintering, or polishing the surface) [16].

Figure 2 presents three major families of AM techniques used for graphene-based composites. 3D printing of polymer/graphene composite parts has been mainly carried out using extrusion-based and powder-based techniques such as fused deposition modeling (FDM), direct ink writing (DIW) and selective laser sintering (SLS), as well as stereolithography (SLA) [17].

\section{Fused deposition modeling}

FDM involves the deposition of thin filaments of thermoplastic polymers or composites onto a support, to create a vertical series of horizontal 2D layers of the part under manufacture (see Fig. 3a). The 3D printer is fed with a spool of a previously extruded filament with standard diameter of $1.75 \mathrm{~mm}$ or $3 \mathrm{~mm}$, which is pushed into a heated nozzle - generally by means of a pair of counter-rotating gears - where it melts and is extruded as a thinner filament (diameter of approximately $0.1-0.2$ $\mathrm{mm}$ ), which is deposited to fabricate the 3D part. The nozzle moves in the $\mathrm{XY}$ direction to build each layer, and vertically (Z-axis) to create other layers [19]. An interesting variant of FDM is Free Form Extrusion (FFE), where a screw extruder replaces the nozzle to produce the thin filament. The extruder can be directly fed by polymers/composites in pellet/powder form, thus widening quite significantly the range of materials that can be printed, considering the relatively limited scope of commercial materials in filament form available for printing. FDM/FFE is by far the most used 3D printing technology [20]. Currently, many 3D printers can handle simultaneously two or more materials. This brings about several advantages: 


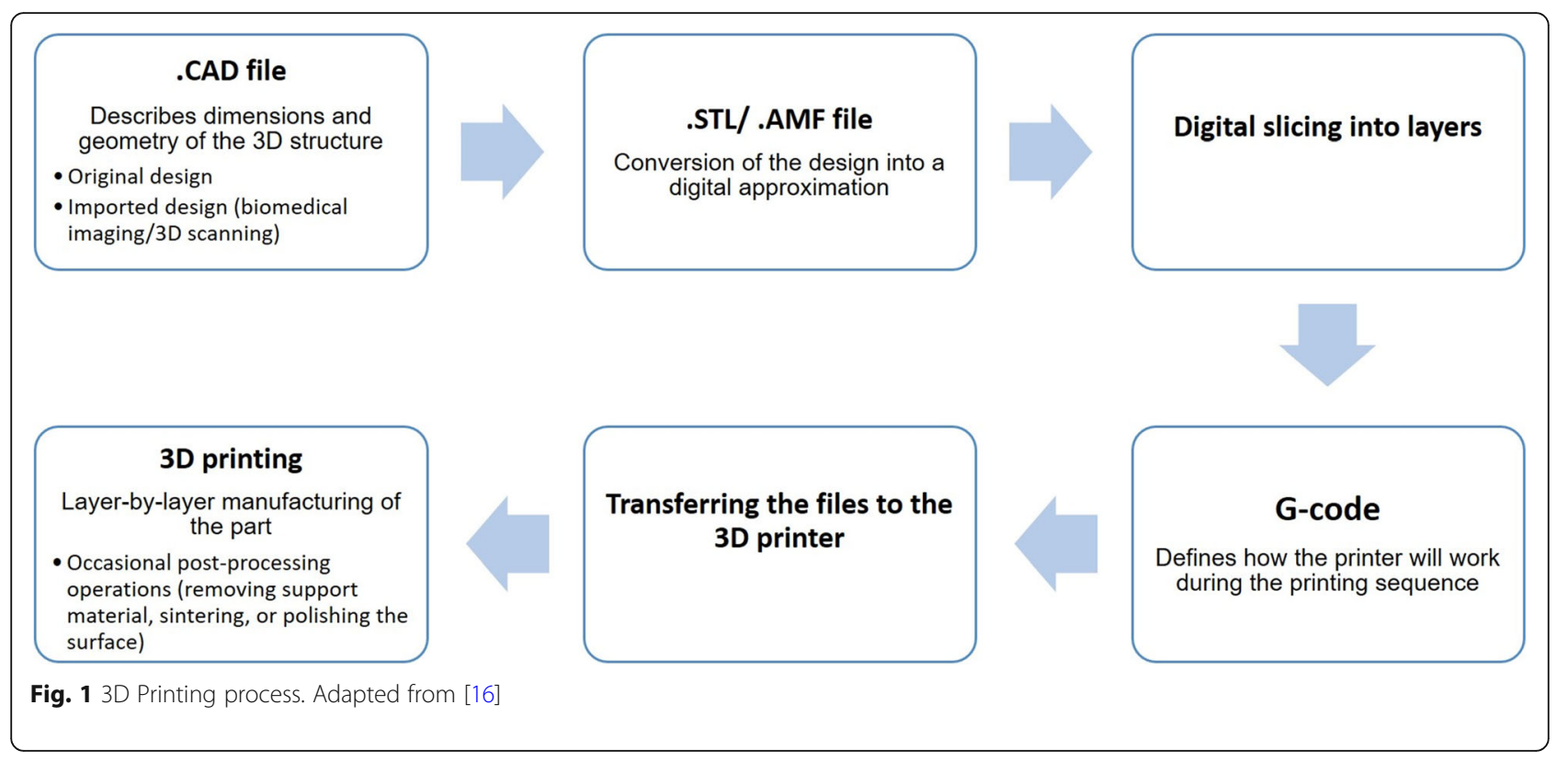

- the production of parts with specific geometrical features; in the case of a geometry consisting of a vertical cylindrical column with a wide disk on top, it is necessary to deposit two materials; one generates the column, while the other will serve as support when printing the disk above; the support material is subsequently removed during postprocessing;

- the production of parts with gradient of particular local properties (e.g., soft vs. rigid zones);

- obtaining aesthetical effects, for example by mixing filaments with different colors and in varying proportions in a single nozzle.

Despite of its apparent simplicity, FDM/FFE is governed by a large number of process parameters, which creates requirements in terms of materials properties, particularly rheological and thermal [21]. Operating parameters include extrusion velocity and temperature, printing velocity, build orientation (the rotation of the part in the manufacturing space around the axes of the machine's coordinate system), deposition sequence (the path taken by the filament during deposition, for example, unidirectional and aligned, unidirectional and skewed, or perpendicular), infill \% ( $0 \%$ is hollow while $100 \%$ is solid), environment temperature, and support temperature. Flow in the nozzle depends on the melt viscosity of the polymer/composite, which is a function of temperature and shear rate, i.e., extrusion velocity and temperature. Upon exiting the nozzle, the molten filament swells, but is simultaneously stretched axially by the printing head (the filament diameter resulting from these two conflicting effects depends on the viscoelastic response of the material). Deposition involves filament deformation and bonding with contacting filaments previously deposited. Therefore, once deposited, each filament should solidify quickly to minimize its deformation due to its own weight and/or the weight of the material

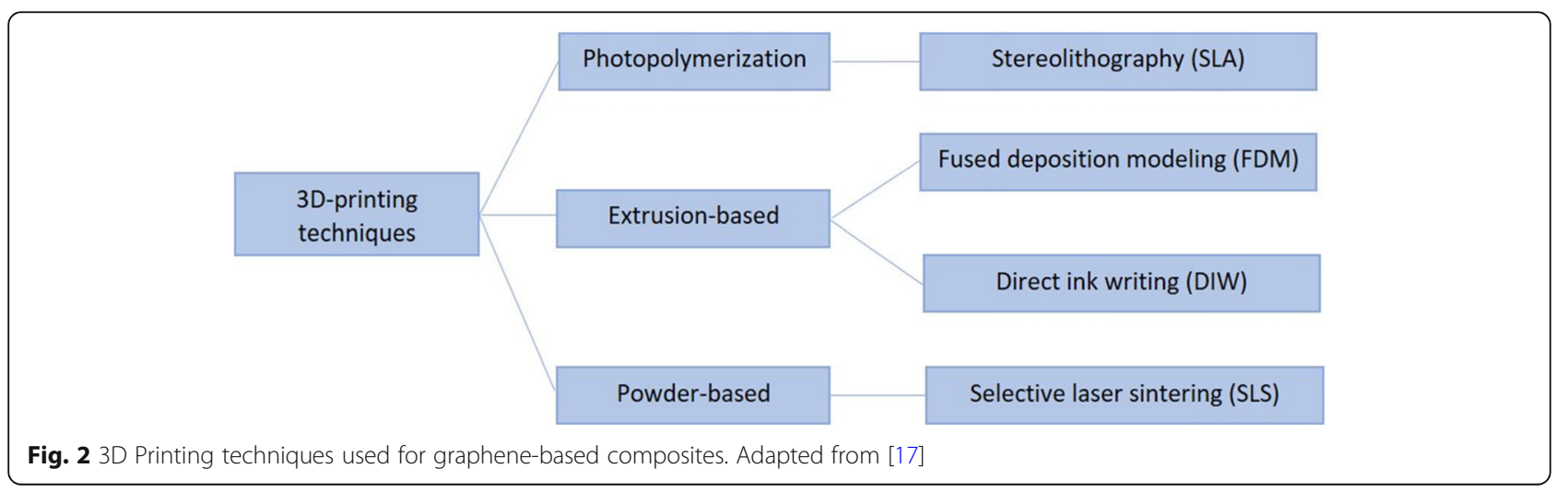




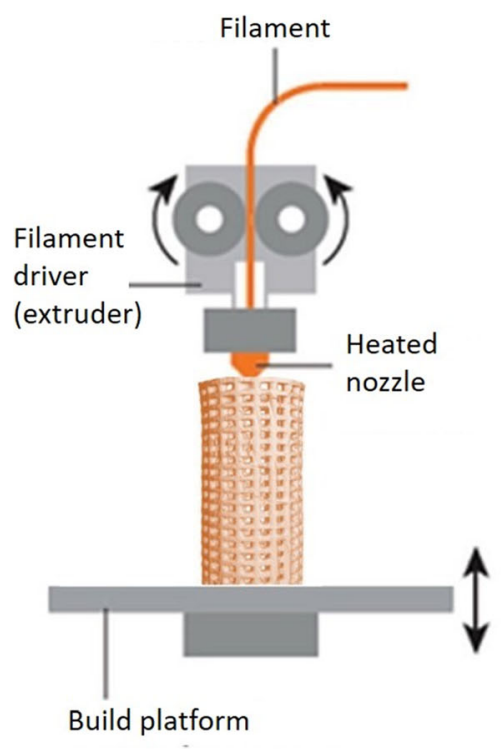

a)

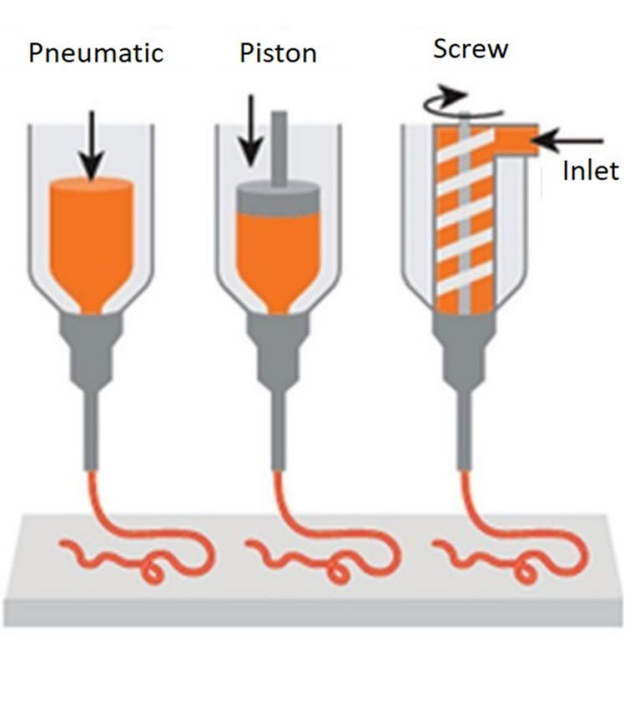

b)

Fig. 3 Schematic representation of extrusion-based techniques, namely a FDM method; b DIW method. Adapted from [18]

that will be deposited above it, thus preserving dimensional accuracy. Conversely, the new filament should remain sufficiently hot during enough time, to ensure adequate bonding (i.e., molecular diffusion) with the neighboring filament(s) [22].

Therefore, process parameters and material properties influence the morphology and properties of printed parts. These are usually significantly anisotropic and may exhibit warping and eventual delamination due to differences in local shrinkage. Adequate bonding between filaments and good porosity control are key factors to obtain quality parts [19,23]. Fiber and nanofiller matrix reinforcement usually cause improvements in the mechanical properties [23].

\section{Direct ink writing}

DIW uses a printing mechanism similar to that of Fused Deposition Modelling but focuses on mesoand micro-scale parts, and generally handles materials with viscosities lower than those of typical polymer melts. The material(s) is (are) supplied under controlled flow rate using a piston (e.g. a syringe), an Archimedes-type screw, or pneumatic force [24] and are heated, so that the nozzle extrudes a liquid "ink" or a "paste" filament that is subsequently printed (Fig. $3 \mathrm{~b})$. The pneumatic force system is easy to install and enables pressure adjustment, whereas the screw system is more appropriate for high viscosity materials [18]. If a low heating temperature is used, cells and bacteria can survive during printing, making DIW suitable for biomedical applications. Biopolymers [25-
27], thermoplastics [28], hydrogels [29-32], organic/ inorganic monomers [33] or graphene-based nanocomposites [34-36] have been printed. Several DIW printers designed for healthcare and food research are currently available in the market, many having a temperature-controlled building platform [17].

As in FDM, the printability of a given material is related to its rheological response. The ink is extruded as liquid, but its viscosity should immediately increase thereafter, so that the printed structure holds without significant dimensional distortion. Hence, rheofluidifying materials, whose viscosity decreases with increasing shear rate, as well as fluids with a yield stress, are recommended. This increase in viscosity can also be induced by cooling, via phase change, or achieved through chemical reactions [37]. Low viscosity (often Newtonian) fluids can also be used in DIW, by extruding into a coagulation liquid where they form a gel. High viscosity inks are thus easier to print, but they tend to clog the nozzle. Proper ink formulation is a key issue in DIW [17].

\section{Stereolithography}

SLA consists on the layer-by-layer deposition of a photo-curable liquid resin/monomer, which cures/polymerizes and solidifies by irradiation with a spatially controlled ultraviolet radiation (UV) light or laser beam, forming the desired pattern (see Fig. 4a). Quick solidification is important in order to hold subsequent layers. After printing, the unreacted resin is removed. The thickness of each layer is controlled by the energy of the 


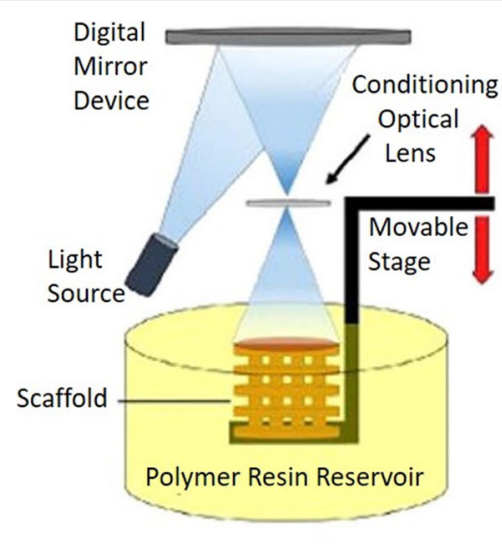

a)

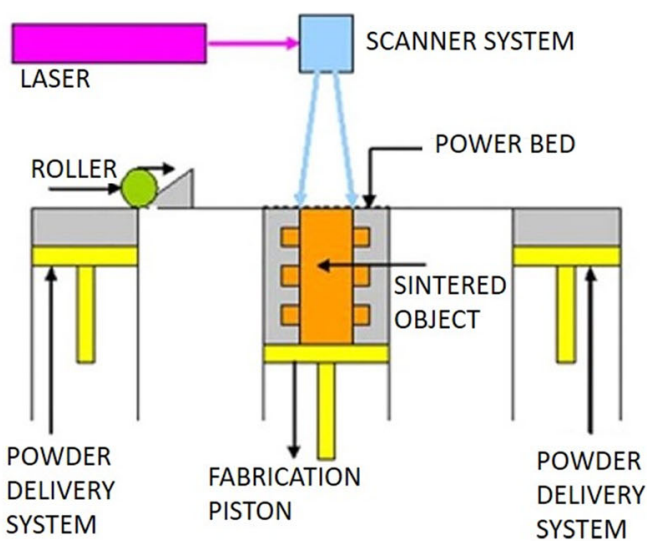

b)

Fig. 4 Schematic representation of laser technologies: a SLA and b SLS. Reproduced with permission from [38]

light source and exposure time. Post-processing may involve heating or further photo-curing, in order to achieve higher mechanical performance [17].

SLA is one of the earliest additive manufacturing techniques. Although relatively slow, expensive and displaying a limited range of materials for printing, it produces high quality parts, and higher resolution that those produced by extrusion-based techniques, with an accuracy as low as $10 \mu \mathrm{m}$ [39].

Materials and nanocomposites for SLA must fulfill two important requirements: i) Fast response to the light irradiation (i.e., rapid initiated polymerization) in order to assure swift solidification; ii) sufficient low viscosity, to allow for the dipping of the resin layer. The latter usually limits the level of filler incorporation and demands a homogeneous filler dispersion [17].

\section{Selective laser sintering}

SLS employs a laser to progressively sinter thin layers of powdered polymer/composite on top of a platform, to create a 3D part. The manufacturing cycle may start by preheating the powder to a temperature just below the formation of a melt. Then, the laser scans one horizontal slice of the geometry, sintering the particles together to create one solid layer. Next, the platform lowers vertically the equivalent to the thickness of one layer. A roller applies a new layer of powder material on top, and the above steps are repeated until printing is completed. The part cools down inside the printer and then is removed and cleaned [40, 41]. Generally, SLS parts exhibit a slightly rough surface, hence post-processing operations are often carried out [42]. Unlike most other AM techniques, SLS does not require the use of support material to generate parts with overhanging features, since the unfused powder supports the part during printing, thus facilitating the production of particularly complex structures [43]. SLS is widely used for advanced applications, such as scaffolds for tissue engineering. Powder particle size and particle distribution determine the density of the printed part. Normally, powder particles with diameters in the range of $10-100 \mu \mathrm{m}$ are used to facilitate spreading, as well as play efficiently the role of support material if unfused [44]. Nevertheless, the porosity of the part can also be controlled through a posttreatment by infiltration [45]. A low melting/sintering material temperature also facilitates the use of the laser.

For the 3D printing techniques most used for biomedical applications, Table 1 identifies the most common polymers and applications, together with the main advantages and limitations.

\section{Graphene-based polymer nanocomposites Graphene and graphene derivative particles}

Graphene consists of a single 2D sheet of $\mathrm{sp}^{2}$-hybridized carbon atoms arranged in a crystalline hexagonal lattice. Its properties are estimated to be similar or even higher than those of carbon nanotubes [47]. Graphene is not permeable to gases, has high flexibility and an optical transmittance of $97.7 \%$ of the total incident light over a wide range of wavelengths [48]. Yet, graphene has found limited practical applications due to the difficulty and cost to obtain, at a commercial production scale, in the form of a single defect-free carbon sheet. A good method to produce graphene derivatives at large scale has been the exfoliation of graphite, using different procedures, such as depicted in Fig. 5a. The most significant methods have been: i) thermal expansion of graphite intercalation compounds (GICs), ii) chemical oxidation of graphite to obtain graphene oxide (GO) [24], and iii) liquid phase exfoliation (LPE) of graphite using liquids of appropriate surface tension and application of high shear forces [51]. 
Table 1 Types of AM in biomedical applications. Adapted from [46]

\begin{tabular}{|c|c|c|c|c|c|}
\hline $\begin{array}{l}\text { AM } \\
\text { Technique }\end{array}$ & Polymer & Resolution & $\begin{array}{l}\text { Biomedical } \\
\text { Applications }\end{array}$ & Advantages & Disadvantages \\
\hline FDM & $\begin{array}{l}\text { Polylactic acid (PLA); Acrylonitrile } \\
\text { butadiene styrene (ABS); } \\
\text { Polycarbonate (PC); Nylon }\end{array}$ & 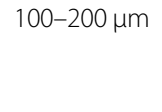 & $\begin{array}{l}\text { Scaffolds for cell } \\
\text { culture, and tissue } \\
\text { engineering }\end{array}$ & $\begin{array}{l}\text { Low cost, high strength, } \\
\text { composite materials, not } \\
\text { using toxic solvents }\end{array}$ & $\begin{array}{l}\text { Nozzle clogging, anisotropy, lower } \\
\text { resolution, thermal degradation of } \\
\text { polymer }\end{array}$ \\
\hline DIW & $\begin{array}{l}\text { Alginate (ALG); Chitosan (CHI); } \\
\text { collagen; gelatin; silk }\end{array}$ & $1-100 \mu \mathrm{m}$ & $\begin{array}{l}\text { Tissue } \\
\text { regeneration, } \\
\text { wound healing, } \\
\text { drug delivery }\end{array}$ & $\begin{array}{l}\text { Structures with different } \\
\text { geometries, sizes, and } \\
\text { materials }\end{array}$ & Formulation of inks \\
\hline SLA & $\begin{array}{l}\text { Photocurable resin (epoxy or } \\
\text { acrylate-based resin) }\end{array}$ & $1.2-200 \mu \mathrm{m}$ & $\begin{array}{l}\text { Scaffolds for cell } \\
\text { culture, tissue, and } \\
\text { organ }\end{array}$ & $\begin{array}{l}\text { High resolution, fast, good } \\
\text { cell viability, nozzle free }\end{array}$ & $\begin{array}{l}\text { Cytotoxicity, high cost, material } \\
\text { limitation, possible harm to } \\
\text { deoxyribonucleic acid (DNA) by UV }\end{array}$ \\
\hline SLS & $\begin{array}{l}\text { Polycaprolactone }(\mathrm{PCL}) \\
\text { Polyamide }(\mathrm{PA}) \text { power }\end{array}$ & $100-200 \mu \mathrm{m}$ & $\begin{array}{l}\text { Temporary and } \\
\text { degradable rigid } \\
\text { implants }\end{array}$ & $\begin{array}{l}\text { Good strength, easy } \\
\text { removal of support, no } \\
\text { solvents required }\end{array}$ & $\begin{array}{l}\text { High cost, medium resolution, } \\
\text { post-processing required }\end{array}$ \\
\hline
\end{tabular}

GICs are formed by the insertion of atomic or molecular layers of different chemical species (alkali metal, metal oxide, metal halogenate, etc.) within the graphene layers, which receive or donate electrons to the intercalated species. The graphite obtained with intercalation compounds presents increased interlayer spacing and weakening of the van der Waals interactions between graphene layers. Subjecting GIGs to sufficiently high temperature or microwave radiation, it will further expand due to vaporization of the intercalate, forming expanded graphite (EG) flakes with nano-size thickness $[48,52]$.

GO is prepared by treatment of graphite flakes with oxidizing agents, bonding oxygen containing functional groups at the graphite surface and edge carbons. In this process the hybridization of part of the graphene carbon changes from $\mathrm{sp}^{2}$ to $\mathrm{sp}^{3}$, expanding the spacing between the graphene layers and facilitating the exfoliation of GO single layers in liquid phase, aided by the application of mechanical forces. GO is electrically insulating, the electrical resistivity varying with the degree of oxidation attained [52], and is stable in aqueous solution due to the polar nature of the oxidizing groups. The subsequent reduction of $\mathrm{GO}$ produces reduced graphene oxide (rGO) which can partially recover the electrical conductivity, but a high oxygen content and physical damage remains in the rGO structure. GO and rGO are less performing than graphene, but the oxygen containing functional groups at the $\mathrm{GO}$ or rGO surface potentiate covalent bonding and strengthen the interface with the polymers, or provide reactivity with biomolecules [24].

LPE of graphite is a cost-effective process that can be up-scaled to mass-production of few layer graphene (FLG), typically based on the application of high shear to graphite suspensions in organic solvents with surface tension near $40 \mathrm{~mJ} \mathrm{~m}^{-2}$ [51], ionic liquids, or water-

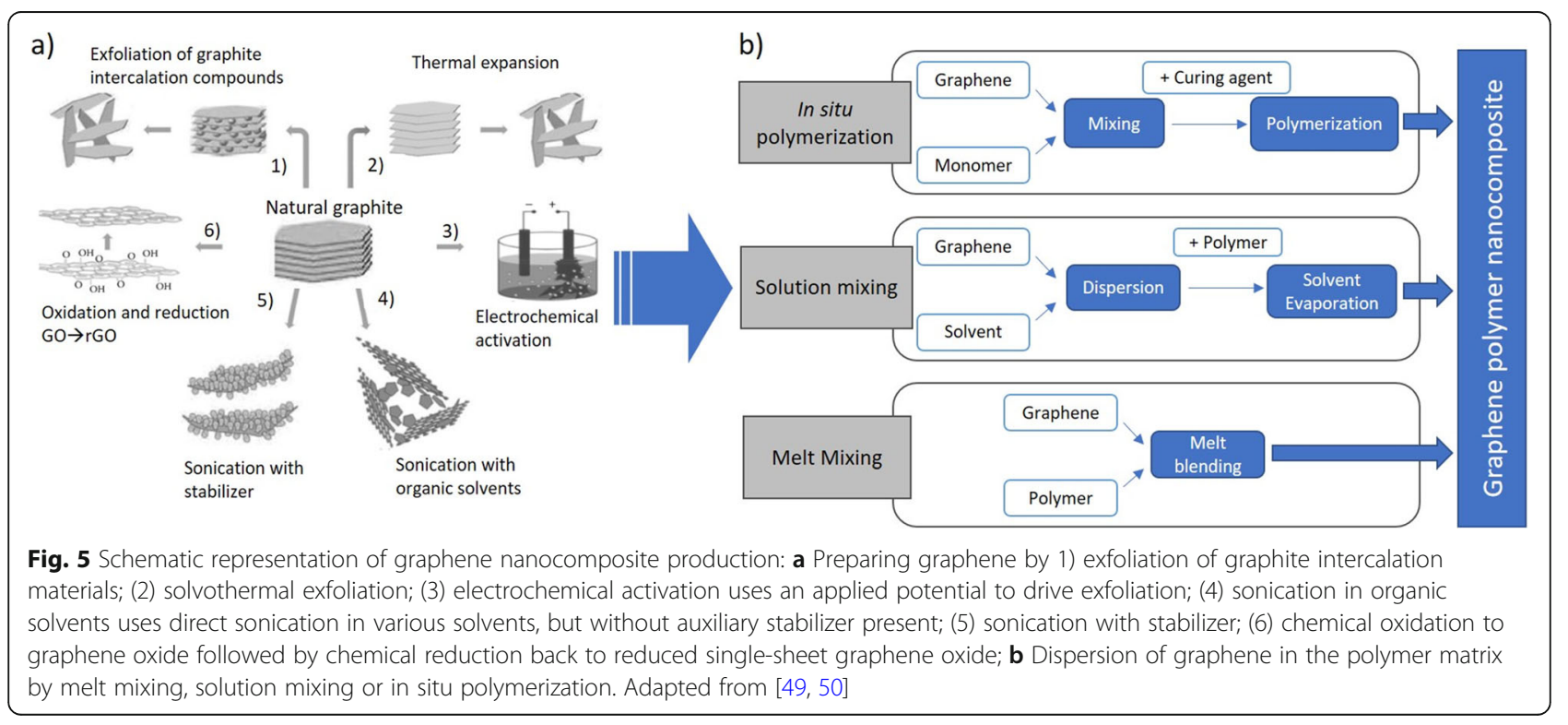


surfactant solutions [53]. The use of organic solvents and ionic liquids is not suited for most biomedical applications, thus LPE of graphite in water solutions of amphiphilic molecules has been favored in this field. LPE produces mainly FLG, with possible formation of a low concentration of monolayer graphene, however requiring the application of high shear rates, larger than $10^{4} \mathrm{~s}^{-1}$.

Graphene nanoplatelets (GNPs) can be obtained from graphite through liquid phase exfoliation processes, exposure of acid-intercalated graphite to microwave radiation, ball milling and shear exfoliation. These techniques produce GNPs with varying morphology, within a range of thicknesses, lateral size, aspect ratio and concentration of defects [54, 55]. Commercially available GNPs are typically formed by a combination of single layer, few layer and nano-sized graphite platelets. Thus, its thickness can vary from 0.34 to $100 \mathrm{~nm}$ within the same production batch [55].

GNPs exhibit interesting properties such as low density, high aspect ratio, 2D morphology, high electrical and thermal conductivity, mechanical toughness, at low cost. Typical mechanical and physical properties (electrical and thermal conductivity) of graphene and graphene derivatives are presented in Table 2 . In this way, GNPs have potential for application in several fields, including thermal interface materials, gas barriers, flame retardants, composites with sensing ability and in the biomedical area [55].

EG and FLG are often used as reinforcement in polymer composites. These nanoparticles are typically produced before composite preparation, and then mixed in the resin or polymer melt using adequate techniques that ensure dispersion of the nanoparticle agglomerates. Only the composites produced in the liquid phase (polymer dilute solutions, monomers for in situ polymerization) may allow the simultaneous LPE of graphite while mixing with the solution.

With the growing interest in graphene-based materials for applications in the medical field, the issue of biocompatibility has gained importance and the studies concerning its cytotoxicity and biocompatibility have multiplied, however there is no scientific consensus on this topic yet [64]. To date, in vitro studies have been performed with bacterial and mammalian cell models, and in vivo studies performed with animals and embryos [65]. The inherent hydrophobic nature of graphene may be responsible for cellular toxicity, since it interferes with the hydrophobic protein-protein interaction in the membrane, interrupting the cell's metabolism, leading to cell mortality [66]. Functionalized graphene-based nanomaterials have shown reduced cellular toxicity [67] since it can help in pacifying the strong hydrophobic interaction of graphene/GO with cells and tissues [64]. Dextran-functionalized GO was found to accumulate in the reticuloendothelial system of mouse such as the liver and spleen after intravenous injection, and could be cleared from its body within a week without significant toxicity [68]. Besides, rGO has greater cellular toxicity than GO, due to the different surface functional group density and oxidation status [67].

However, it is not possible to make general statements on graphene-based materials safety or toxicity in eukaryotic cells, since it is strongly influenced by several factors such as the production methods, concentration, shape, distribution, surface area, number of layers, lateral dimensions, hydrophobicity, purity, particulate state, surface functionalization [69-71] and even to the type of cells that graphene was exposed to [72]. For instance, Wei et al. reported that pristine GO inhibited the proliferation of bone mesenchymal stem cells (BMSCs) at a high concentration of $10 \mu \mathrm{g} / \mathrm{mL}$, but enhanced their proliferation at a low concentration of $0.1 \mu \mathrm{g} / \mathrm{mL}$ [73]. Similarly, Zhang et al. investigated the toxic effects of GO nanosheets on BMSCs. A high concentration of GO inhibited cell viability and membrane integrity. It was observed that the toxic effects of GO on BMSCs occur in a dose-dependent manner through the mitochondrial apoptotic pathway and autophagy. Exposure of BMSCs to $\mathrm{GO}$ at $0.1,0.5$ and $2.5 \mu \mathrm{g} / \mathrm{ml}$ for $24 \mathrm{~h}$ resulted in a slight increase in apoptosis by 5,7 and $8 \%$ [74].

In addition, the in vivo effect of graphene-based materials is also dependent on the dose/time exposure, administration route, and the characteristics of the animals used in the experiment $[65,75]$. Thus, conflicting results on the toxicity/biocompatibility of graphene derivatives have been reported. Some studies suggested that graphene-based materials are beneficial [76-81] and

Table 2 Mechanical and physical properties of graphene-based materials

\begin{tabular}{|c|c|c|c|c|c|}
\hline \multirow[t]{2}{*}{ Properties } & \multicolumn{5}{|c|}{ Graphene-based materials } \\
\hline & Graphene & GO & rGO & Graphite & GNPs \\
\hline 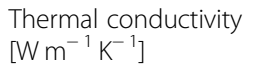 & $\begin{array}{l}\sim 5000 \\
{[56]}\end{array}$ & $3000[57]$ & $30-250[58]$ & $3000[52]$ & $\begin{array}{l}5000 \\
{[59]}\end{array}$ \\
\hline $\begin{array}{l}\text { Young's Modulus } \\
\text { [GPa] }\end{array}$ & $\begin{array}{l}\sim 1000 \\
{[56]}\end{array}$ & $200[60]$ & $250[60]$ & $20[61]$ & $\begin{array}{l}1000 \\
{[62]}\end{array}$ \\
\hline $\begin{array}{l}\text { Electrical conductivity } \\
{\left[\mathrm{S} \mathrm{m}^{-1}\right]}\end{array}$ & $\sim 10^{6}[63]$ & $\begin{array}{l}\text { Insulator } \\
{[60]}\end{array}$ & $\begin{array}{l}\sim 667 \\
{[58]}\end{array}$ & Insulator & $10^{5}[59]$ \\
\hline
\end{tabular}


others mention adverse responses including cytotoxicity $[82,83]$, tissue fibrosis [84], and inflammatory cell recruitment, usually in lung and liver [83, 85-87].

\section{Nanocomposites preparation methods}

Most preparation methods of commercial graphenederivatives are based on the bulk exfoliation of graphite. Given the atomically flat surface of graphene, those materials may be obtained as cohesive agglomerates of individual nanoparticles, stabilized by non-covalent interactions through Van der Waals forces [88]. To fully explore the reinforcing effect and the functional properties resulting from the incorporation of graphenederivatives into polymer matrices, it is essential to guarantee the uniform dispersion and distribution of the individual nanoparticles, in order to generate a large interfacial area between the composite components [89].

There are three main routes economically viable and scalable to produce well-dispersed polymer composites, as summarized in Fig. 5b. Solution and melt mixing are essentially based on the mechanical action and physical interactions between the polymer and nanoparticles, while in situ polymerization also uses a chemical approach [90].

Solution mixing is especially used for the small-scale manufacture of polymer composites whenever they are soluble in aqueous or organic solvents [91]. The technique entails the dispersion of the nanoparticles in a solvent by mechanical mixing, magnetic stirring, or sonication, followed by the addition of the polymer solution and mixing again by the same methods. The composite is obtained by removing the solvent by precipitation in a non-solvent or by direct solvent evaporation [92]. During mixing, the nanoparticles further separate/expand due to diffusion of the low viscosity polymer solution, and may adsorb polymer molecules at their surface, which helps preventing reagglomeration when the solvent is evaporated.

Melt mixing uses polymer processing equipment, typically internal mixers, or twin-screw extruders, to subject the flowing polymer melt and the graphene-based reinforcement to high hydrodynamic (shear and extensional) forces and complex flow fields. Processing parameters such as temperature, mixing speed, residence time and mixer geometry need to be adequately selected to obtain good dispersion levels [93]. Nevertheless, melt mixing generally attains lower dispersion levels than the remaining methods, although it exhibits strong advantages, such as avoiding the use of solvents, easily scaling to industrial production and high yield. The composite can be readily processed into a final product, or used as a masterbatch, i.e., diluted into the polymer using the same processing method to obtain the desired filler incorporation level.
In situ polymerization involves the preparation of a stable dispersion/suspension of the graphene-derivative particles in the liquid monomer, followed by polymerization. The latter may be initiated by heat, radiation, or by the addition of a catalyst. If the nanoparticles are functionalized with the adequate chemical functions, reaction may occur with the growing polymer chains during polymerization, enhancing interfacial strength and avoiding nanoparticle reagglomeration [88, 91].

For each of the above methods, Table 3 presents a list of polymers used for the manufacture of graphene-based composites, together with their advantages and limitations.

Kim et al. compared the performance polyurethane (PU)/graphene-based nanocomposites produced by different methods using the procedure represented in Fig. 6 [32]. Solvent-based methods yielded the best dispersion, improving the composite properties. Indeed, composites obtained by in situ polymerization exhibited a slightly higher percolation threshold when compared to those prepared by solution mixing. The electrical conductivity of the composites produced by in situ polymerization and solvent mixing was higher relative to that of materials produced by melting mixing, at similar reinforcement concentration [96].

Properties of 3D printed graphene-based nanocomposites 3D-printing of graphene-based nanocomposites has been the focus of extensive research, aiming to explore the potential to develop components for advanced applications in electronics, healthcare, energy storage, among others. Table 4 compares results obtained for the properties of 3D printed composites produced with different polymers and using different AM techniques. Despite the advantages of these technologies, some practical issues such as efficiency, cost, feasibility of mass production, still prevents the large-scale adoption of this solution [97].

\section{D printing of graphene-based polymer composites for biomedical applications}

\section{Scaffolds for tissue engineering}

The development of scaffolds with higher mechanical properties suitable for in vivo application requires sophisticated manufacturing methods. Additive manufacturing techniques brought the possibility to process composite scaffolds with fine control of geometry and size, enabling the development of complex and personalized shapes with vast potential to regenerate distinct tissues [98].

With the advances of 3D-printing, the production of 3D biological constructs that mimic the structure and function of native tissues with precise control over the 
Table 3 Preparation methods of graphene-based composites

\begin{tabular}{|c|c|c|c|c|}
\hline $\begin{array}{l}\text { Preparation } \\
\text { method }\end{array}$ & Polymer matrix & Advantages & Disadvantages & Ref \\
\hline $\begin{array}{l}\text { Solution } \\
\text { Mixing }\end{array}$ & $\begin{array}{l}\text { PC; Polymethylmethacrylate (PMMA); } \\
\text { Polyvinyl alcohol (PVA); Polystyrene } \\
\text { (PS); Polyurethane (PU) }\end{array}$ & Inexpensive; Homogeneous dispersion. & Need to remove solvents & $\begin{array}{l}{[3,} \\
88, \\
90 \\
94]\end{array}$ \\
\hline Melt Mixing & $\begin{array}{l}\text { PU; Polyethylene terephthalate (PET); } \\
\text { PLA; PC }\end{array}$ & $\begin{array}{l}\text { Applicable to polar and non-polar polymers; } \\
\text { does not use solvents; adequate for both small } \\
\text { and large-scale production. }\end{array}$ & $\begin{array}{l}\text { Less effective in dispersion; } \\
\text { possible buckling, rolling, or } \\
\text { shortening of graphene sheets. }\end{array}$ & $\begin{array}{l}\text { [90, } \\
91, \\
95]\end{array}$ \\
\hline $\begin{array}{l}\text { In Situ } \\
\text { Polymerization }\end{array}$ & $\begin{array}{l}\text { PA; Polyethylene (PE); Polypyrrole } \\
\text { (PPy); PMMA }\end{array}$ & $\begin{array}{l}\text { Applicable to insoluble or thermally unstable } \\
\text { polymers. }\end{array}$ & Need to remove solvents. & $\begin{array}{l}{[88,} \\
92, \\
95]\end{array}$ \\
\hline
\end{tabular}

positioning of both cells or other biological components (proteins, growth factors...) and biomaterials, called biofabrication, is now possible [99, 100]. Bioprinting such constructs comprises several technologies such as SLS, SLA, FDM or inkjet bioprinting, already addressed in section 2. Most of them were originally developed as AM technologies for rapid prototyping, but are included as biofabrication strategies when used for biomedical applications [99, 101].

The bioprinting process can be performed by two different approaches designated as pre-seeding, or direct, and post-seeding, or indirect [102]. The former involves the simultaneous printing of materials and cells combined, while the latter consists of initially printing the material and then co-culturing it with the proper cells. The studies found in literature related with graphenebased 3D-printed scaffolds, which will be overviewed in this section, fall under the category of post-seeding bioprinting.

Recently, Belaid and co-workers [103] developed a 3D-printed scaffold of PLA reinforced by the incorporation of $\mathrm{GO}$ at different concentrations (0.1, 0.2 and $0.3 \mathrm{wt} \%)$. A composite polymer solution of $\mathrm{GO}$ and PLA was cast to form a film that was cut into pieces and introduced into a single-screw extruder, at $200{ }^{\circ} \mathrm{C}$. A filament with a diameter of $1.75 \mathrm{~mm}$ was obtained and used to print the 3D-scaffolds by FDM. To facilitate bone regeneration, the authors generated scaffolds with a porous interconnected network and a pore size around $300 \mu \mathrm{m}$, corresponding to an infill of $70 \%$. With the incorporation of GO, the scaffolds revealed a rougher and hydrophilic surface, when compared to control PLA scaffolds. Tensile tests showed that the mechanical properties were improved with the GO incorporation (30\% increase of the Young's modulus with $0.3 \% \mathrm{GO}$ ) - Fig. 7. Composite scaffolds were also biocompatible as the cell viability, attachment, proliferation, and differentiation assays using MG-63 osteosarcoma cells showed. They promoted cell proliferation and mineralization more efficiently than pure PLA scaffolds which potentially allow bone formation [103].

The need for conductive and mechanically robust, biocompatible, and biodegradable materials in tissue engineering (TE) is constantly increasing. The advantages of electrical conductivity and electrical stimulation (ES) have been recognized and explored in biomedical field [104], since cell adhesion and differentiation are affected by a residual permanent charge on the materials surface. Therefore, it is expected that the use of ES after biomaterial implantation would induce osteointegration. Graphene-based materials have been proposed as additives to produce electrically conducting composites demonstrating that the simple presence of the electrical stimuli of the materials contribute to improve cellular functions [104, 105]. However, as mentioned above, there is no consensus about graphene cytotoxicity and some authors still mention some risks [106]. Wang and colleagues printed PCL-graphene scaffolds loaded with $0.13 \mathrm{wt} \%, 0.50 \mathrm{wt} \%$ and $0.78 \mathrm{wt} \%$ of graphene and associated a non-invasive microcurrent therapy to treat rat calvaria critical size bone defects [106]. The blended composite material was cut into small pellets for processing. The melt processing temperature was $90{ }^{\circ} \mathrm{C}$, $220 \mu \mathrm{m}$ of slice thickness, $22 \mathrm{rpm}$ of screw velocity, and $20 \mathrm{~mm} / \mathrm{s}$ of deposition velocity. The fabrication process was performed at room temperature. A $0^{\circ} / 90^{\circ}$ lay-down pattern was used to obtain pores with a regular geometry, a constant filament diameter of $330 \mu \mathrm{m}$, and a filament distance of $680 \mu \mathrm{m}$. Thereafter, MC3T3 preosteoblastic cells were seeded on the scaffolds - Fig. 8. These results showed that cell proliferation was stimulated with the increase of graphene concentration and no significant cytotoxicity was found. Printed scaffolds with 0.78 wt.\% induced an acceptable level of immune response, revealed by the low levels of tumor necrosis factor-alpha (TNF $\alpha)$ and interleukin-1-beta (IL-1 $\beta)$, suggesting high potential for in vivo applications. The incorporation of graphene and the application of electrical stimulation $(10 \mu \mathrm{A})$ led to an increase in cell migration, 


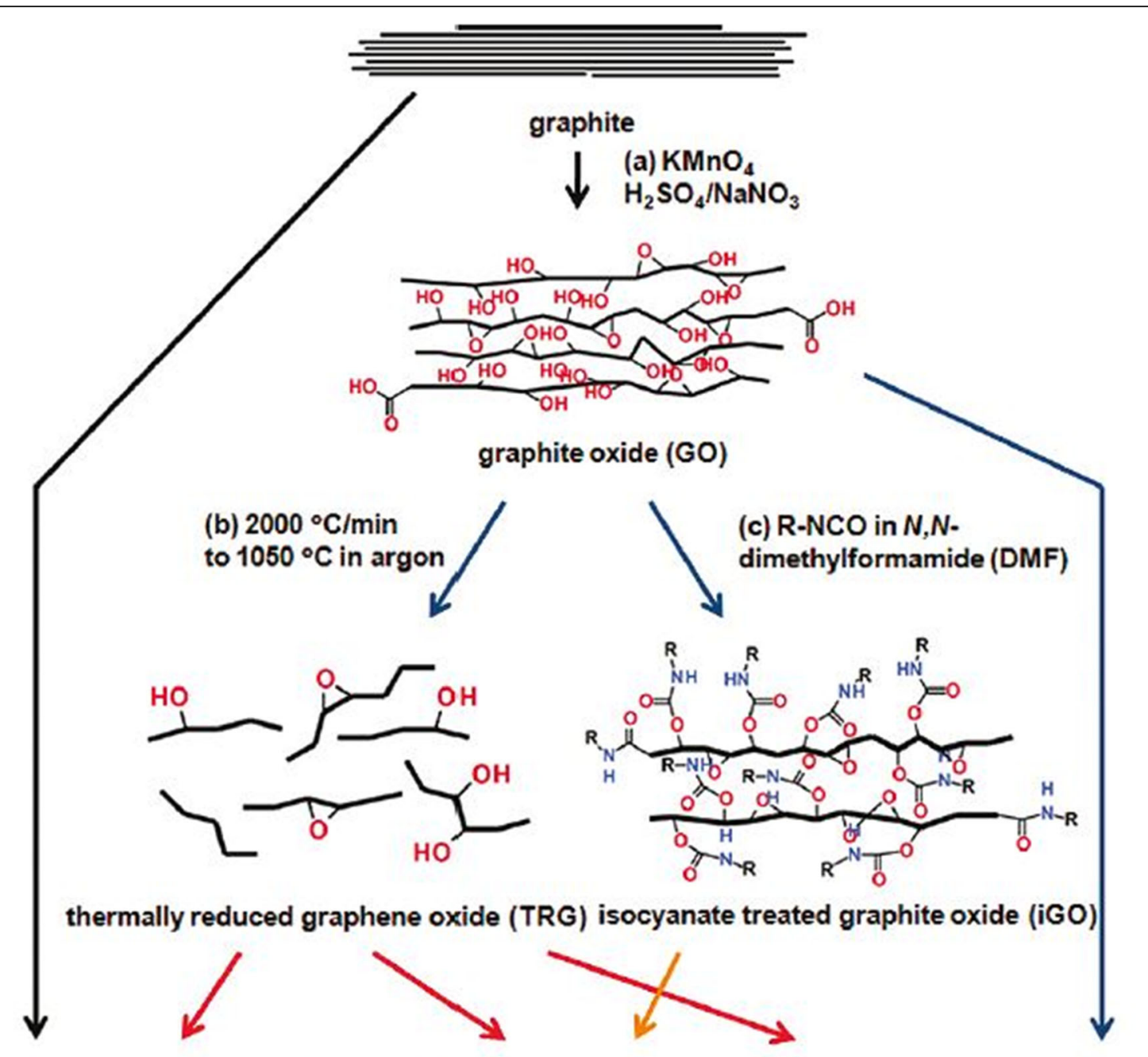

(d) melt compounding at $180^{\circ} \mathrm{C}$

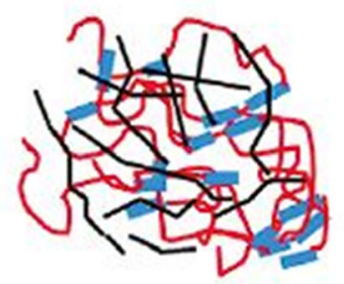

(e) solvent blending in DMF

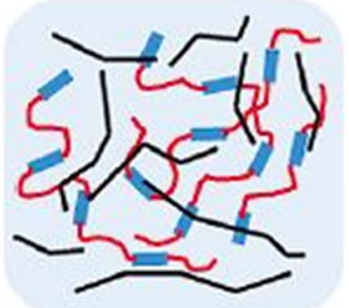

(f) in-situ polymerization in DMF

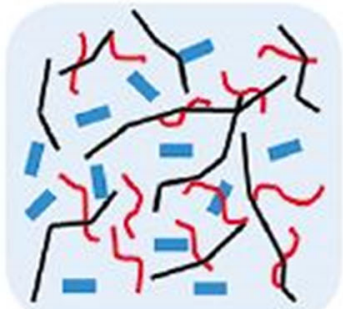<smiles>CC(C)(C)OC(=O)Nc1ccc(Cc2ccc(NC(=O)OCCCCOC(=O)Nc3ccc(Cc4ccc(N=C=O)cc4)cc3)cc2)cc1</smiles>

Fig. 6 Schematic representation of TPU/Graphene Composite Preparation: a After oxidation of graphite functionalized layers of graphene can be obtained by (b) Rapid Thermal Expansion or (c) Organic Modification with Isocyanate in dimethylformamide (DMF) (iGO); (d) Graphite can be mixed with TPU via Melt mixing, or (e) Solvent mixing, followed by solvent removal; (f) In opposite, composites can be produced monomers using In situ polymerization. Black lines represent graphitic reinforcements. TPU hard and soft segments are represented by short blue blocks and thin red curves, respectively [96] 
Table 4 Properties of 3D printed graphene-based composites

\begin{tabular}{|c|c|c|c|c|}
\hline Technique & Matrix & Filler & Properties & Ref \\
\hline SLA & $\begin{array}{l}\text { Photopolymer } \\
\text { (Envision TEC PIC } 100 \\
\text { resin) }\end{array}$ & GO & $\begin{array}{l}0.2 \mathrm{wt} . \% \mathrm{GO} \text { increased } 62.2 \% \text { and } 12.8 \% \text { the tensile strength and ductility, respectively of the } \\
\text { printed composite. }\end{array}$ & [54] \\
\hline \multirow[t]{3}{*}{ DIW } & Polyaniline (PANI) & & Specific capacitance of the printed supercapacitor: $1329 \mathrm{mF} \mathrm{cm}^{-2}$. & [56] \\
\hline & $\begin{array}{l}\text { Polydimethylsiloxane } \\
\text { (PDMS) }\end{array}$ & & $\begin{array}{l}\text { The printed device exhibited a resistivity of } 1660 \Omega . \mathrm{cm} \text { at a low GO percolation threshold (0.83 } \\
\text { vol.\%) }\end{array}$ & [57] \\
\hline & Epoxy & Graphene & $\begin{array}{l}\text { Printed composites with } 10 \text { wt.\% of graphene presented flexural modulus of } 3.2 \mathrm{GPa} \text { and bulk } \\
\text { resistivity of } 1 \times 10^{3} \Omega \text {.m, i.e., five orders of magnitude lower than that of the neat epoxy. }\end{array}$ & [58] \\
\hline SLS & PA & & $\begin{array}{l}\text { Tensile modulus for PA-rGO compared to PA ( } 221 \pm 17 \text { vs } 149 \pm 26 \mathrm{MPa} \text { ) and similar tensile } \\
\text { strength. }\end{array}$ & [59] \\
\hline FDM & $A B S$ & & $\begin{array}{l}\text { Electrical conductivity increased to } 1.78 \times 10^{-7} \text { and } 1.05 \times 10^{-3} \mathrm{~S}^{-\mathrm{m}^{-1}} \text { with the addition of } 0.4 \\
\text { and } 5.6 \mathrm{wt} \% \text { of graphene, respectively }\end{array}$ & [60] \\
\hline
\end{tabular}
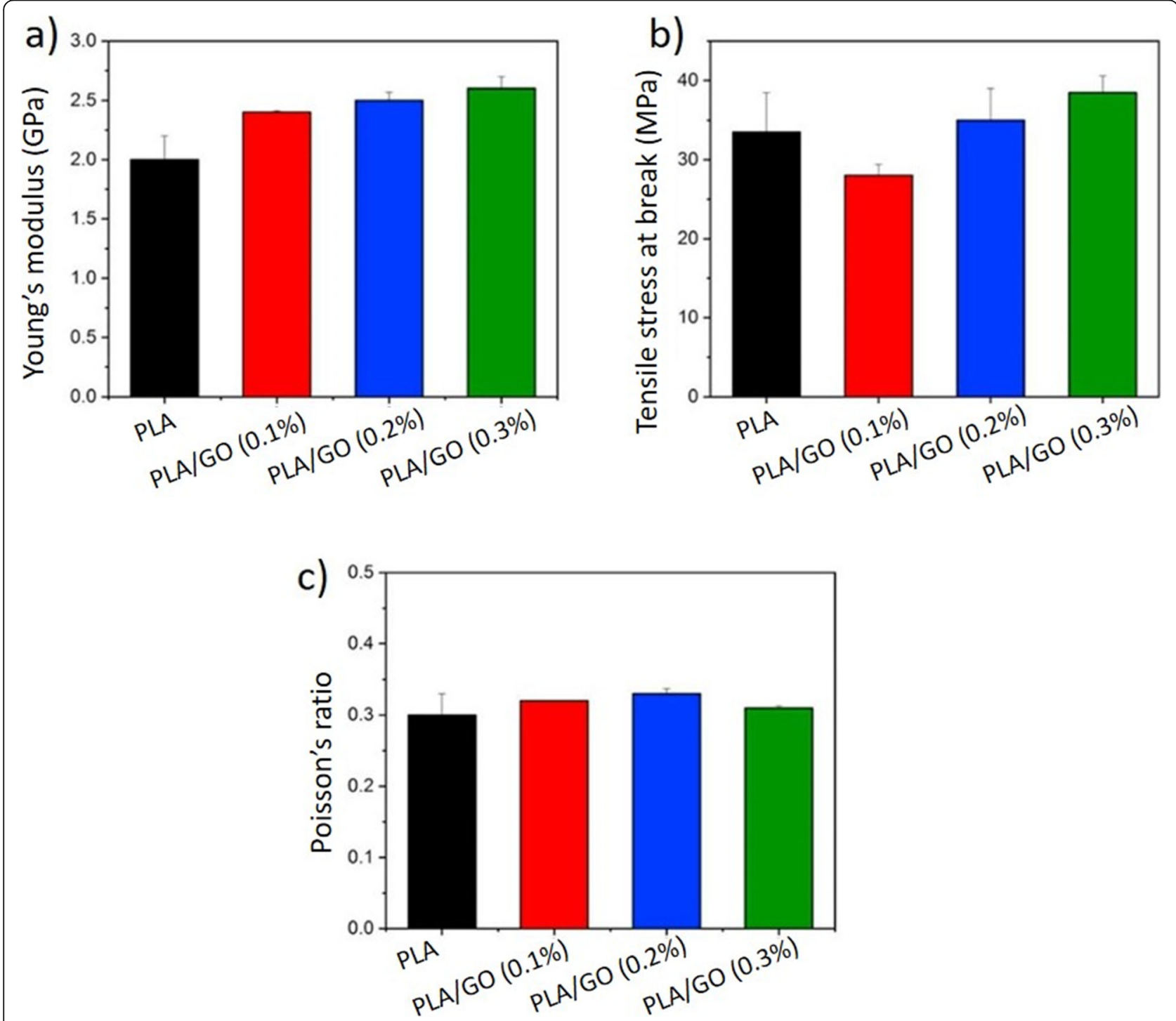

Fig. 7 Mechanical properties of PLA and PLA/GO scaffolds produced by FDM: a Young's modulus, $\mathbf{b}$ Tensile stress at break, and $\mathbf{c}$ Poisson's ratio. Reproduced with permission from [103] 


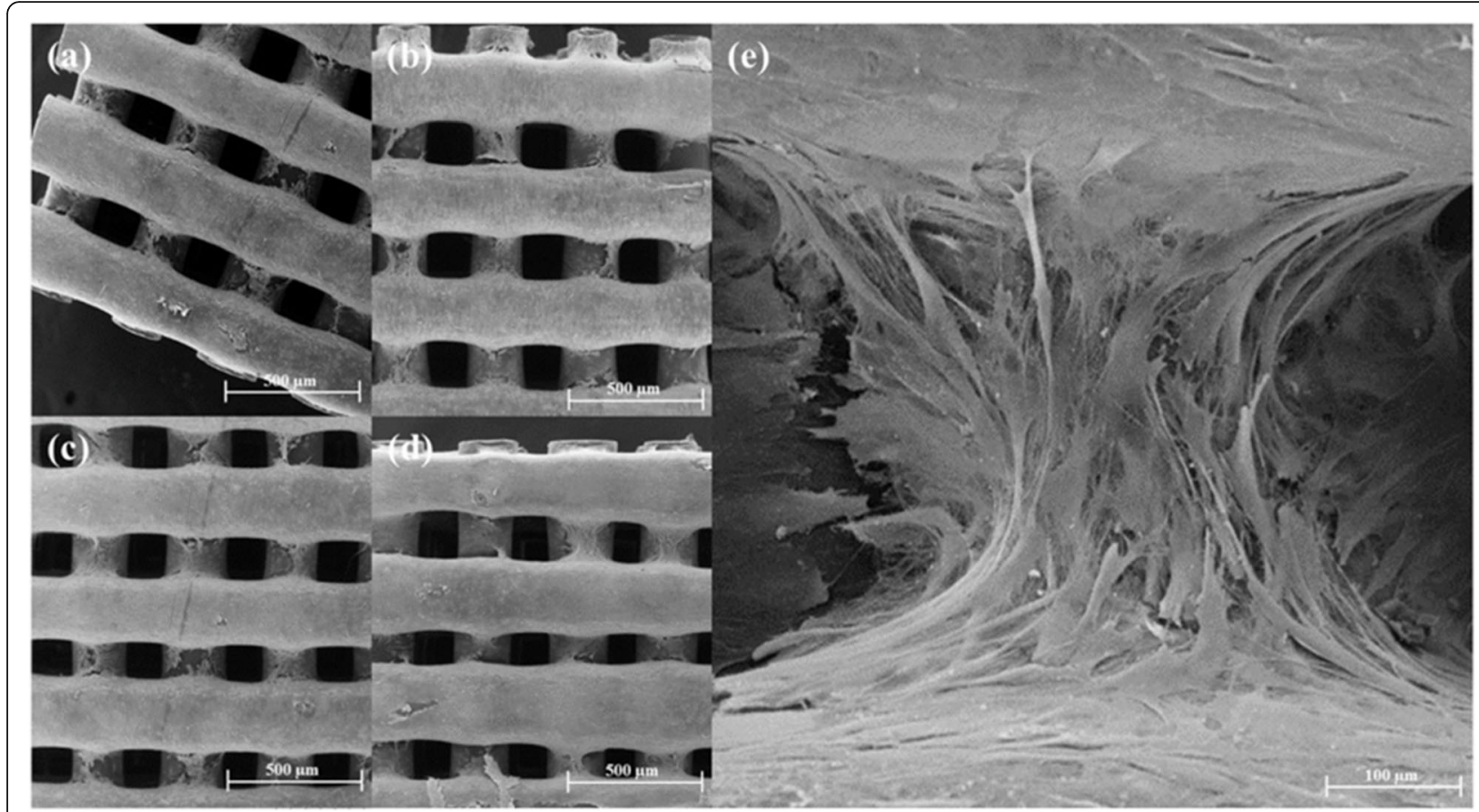

Fig. 8 SEM images of cell seeded scaffolds after 14 days. a PCL; b PCL/graphene (0.13 wt\%); c PCL/graphene (0.50 wt\%); d PCL/graphene (0.78 wt\%); e Zoom up image for cell bridging. Reproduced with permission from [106]

leading to new tissue formation, well-organized tissue deposition and bone remodeling, as can be seen in Fig. 9 [106].

In another study, Jakus et al. [107] developed 3Dprintable graphene inks and used them to produce electrically conductive, mechanically resilient, and biocompatible scaffolds with high graphene content (20 and 60 vol\% of solid). The ink contained graphene flakes and polylactide-co-glycolide (PLGA) and was produced by combining a solution of PLGA and dichloromethane with a graphene dispersion, followed by solvent evaporation. The authors used this ink via extrusion-based 3D printing to create mechanically robust graphene scaffolds. That retained electrical conductivity greater than $800 \mathrm{~S} / \mathrm{m}$. These composite scaffolds supported cells adhesion/proliferation, as well as neurogenic differentiation, as illustrated in Fig. 10. On day 14, a distinct difference in cell morphology was observed, where human mesenchymal stem cells (hMSC) on $20 \mathrm{vol} \%$ graphene scaffold exhibited a sheet-like morphology, characteristic of adherent cell types such as fibroblasts. In contrast, cells on $60 \mathrm{vol} \%$ graphene scaffold presented highly elongated morphologies similar to uni- or multipolar neurons - Fig. 10. In vivo experiments of 30 days in mice showed promising biocompatibility with no evidence for the accumulation of graphene flakes in the kidney, liver, or spleen. Besides, the scaffolds present exceptional handling characteristics being able to apply in fine surgical procedures [107].

Sayyar et al. [108] used different percentages of rGO to reinforce a chitosan -lactic acid matrix and produce conductive hydrogels. These composites were easily processed into 3D scaffolds by extrusion-printing. Scaffolds with 30 layers of each graphene/chitosan dispersion were printed from a $200 \mu \mathrm{m}$ diameter nozzle, at $0^{\circ} / 90^{\circ}$ orientation, a feed rate of $150 \mathrm{~mm} \cdot \mathrm{min}^{-1}$ and with a strand spacing of $0.6 \mathrm{~mm}$. The addition of graphene led to significant improvements in terms of mechanical strength. An addition of $3 \mathrm{wt} . \%$ of graphene caused an increase over $200 \%$ in tensile strength. The resulting structures were seeded with fibroblast $\left(\mathrm{L}^{-929}\right)$ cells that adhered and proliferated on several layers of the 3D scaffold. These scaffolds revealed to be excellent conducting substrates for the growth of electro-responsive cells [108].

Zhou and co-workers [109] combined GO in different concentrations $(0,0.05,0.1,0.25,0.5$ and $1 \mathrm{mg} / \mathrm{mL})$ with a gelatin-methacrylate (GelMA) and poly (ethylene glycol) diacrylate (PEGDA) solution to produce a biocompatible photopolymerizable ink and then 3D-printed scaffolds. GelMA-PEGDA inks with and without GO were placed on the $\mathrm{z}$-control movable platform and printed by SLA, using a table-top stereolithographybased printer that applied UV laser. The printing 

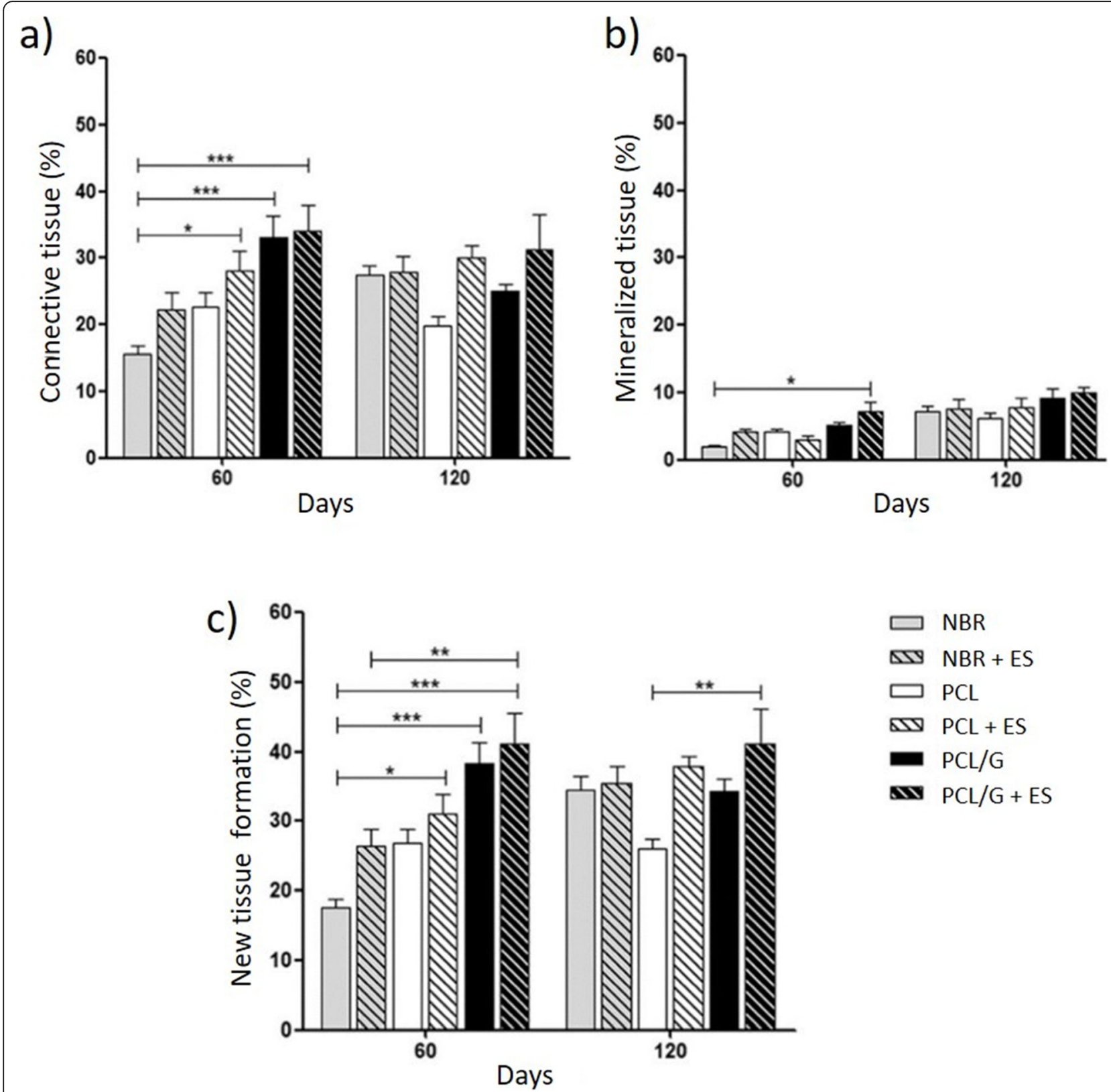

Fig. 9 Evolution in time of the formation of (a) Connective tissue; (b) mineralized bone tissue; and (c) cumulative tissue formation (connective + bone tissues) on the PCL and PCL/0.78 wt\% of graphene (G) scaffolds, with and without electrical stimulation (ES). NBR stands for "natural bone regeneration"or control group. Reproduced with permission from [106]

parameters were: $200 \mu \mathrm{m}$ diameter laser beam, $25 \mu \mathrm{J}$ intensity output of $20 \mathrm{kHz}$ emitted UV, and $10 \mathrm{~mm} / \mathrm{s}$ printing speed. Human MSCs spread and extended on these scaffolds, after 5 days of culture. The results showed that the optimal combination was $15 \%$ GelMA+ PEGDA with GO incorporated at $0.1 \mathrm{mg} / \mathrm{mL}$, as seen in Fig. 11. Moreover, the authors showed that these GelMA-PEGDA-GO scaffolds induced chondrogenic differentiation of Human MSCs and promoted the glycosaminoglycan and collagen levels. Collagen II,
SOX 9 and Aggrecan gene expressions associated with chondrogenesis were also greatly promoted on the scaffolds. Such scaffolds are excellent candidates for cartilage regenerative applications.

Composite scaffolds of polyether ether ketone (PEEK)/ PVA reinforced with GO was developed by Feng and coworkers using a SLS system envisaging bone regeneration [110]. The resulting scaffolds presented good hydrophilicity and degradability. For a GO loading of 1 wt.\%, the strength and modulus of PEEK/PVA scaffolds 


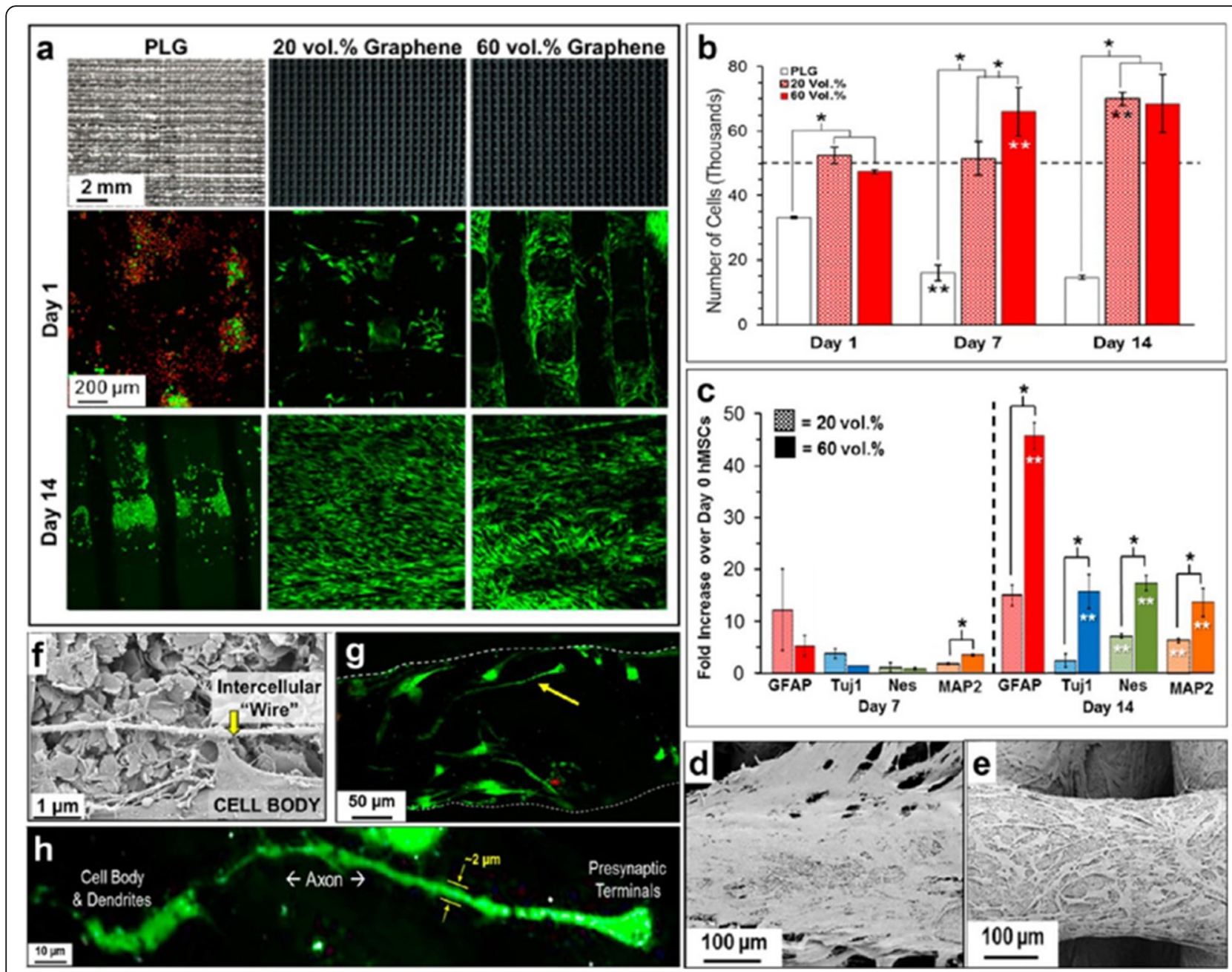

Fig. 10 a Images and scanning laser confocal 3D reconstruction projections of live stained (green) and dead stained (red) hMSCs on different scaffolds after 1, 7 and 14 days of seeding. b Number of hMSCs present on scaffolds as a function of composition and days after seeding, according to DNA quantification. Dotted line represents initial cell seeding number. c Neurogenic relevant gene expression of cells on scaffolds with 20 and 60 vol\% graphene after 7 and 14 days of seeding, normalized to expression of day 0 (unseeded hMSCs). SEM micrographs of hMSCs on (d) 20 and (e) 60 vol\% graphene scaffolds 7 days after seeding. f High-magnification SEM micrograph of cells on day 7, 60 vol\% graphene scaffolds, revealing hMSC connecting via a small "intercellular" wire. $\mathbf{g}$ Scanning laser confocal 3D reconstruction of live (green) and dead (red) cells on day 14 for 60 vol\% graphene scaffolds and (h) detail of cell indicated by yellow arrow in (f). For panels b and c, "**" indicates significance of $p<0.05$ between compared groups $(n=4)$; "**" indicates significant $(p<0.05)$ difference over previous time point for the same material group. Reproduced with permission from [107]

increased by $97.16 \%$ and $147.06 \%$, respectively. In vitro tests with MG63 cells revealed that the scaffolds promoted cell attachment and proliferation as well as osteogenic differentiation and bone regeneration in vivo, with rabbits [110].

In addition to all outstanding mechanical and electrical properties, graphene can be exploited in the medical field because of its antibacterial activity. Angulo-Pineda et al. explored this property and developed SLA composite scaffolds of PCL filled with conductive thermally reduced graphene oxide nanoparticles at concentration above the percolation threshold. By applying a voltage along of their surface, a bactericidal effect was observed.
Moreover, under the same regime of ES, the adhesion and viability of human stem cells were further enhanced when compared with pure PCL scaffolds with and without ES [111]. The antibacterial activity was also observed by Zhang and co-workers in 3D printed Ag-GO nanocomposite scaffolds [112] as well as by Cabral et al., that produced tricalcium phosphate/gelatin/chitosan scaffolds reinforced with rGO displaying antimicrobial activity without compromising osteoblasts' viability and proliferation [113].

Cryogenic 3D printing is a recently developed biofabrication process that allows the production of scaffolds with a predesigned shape, controllable architecture, and 

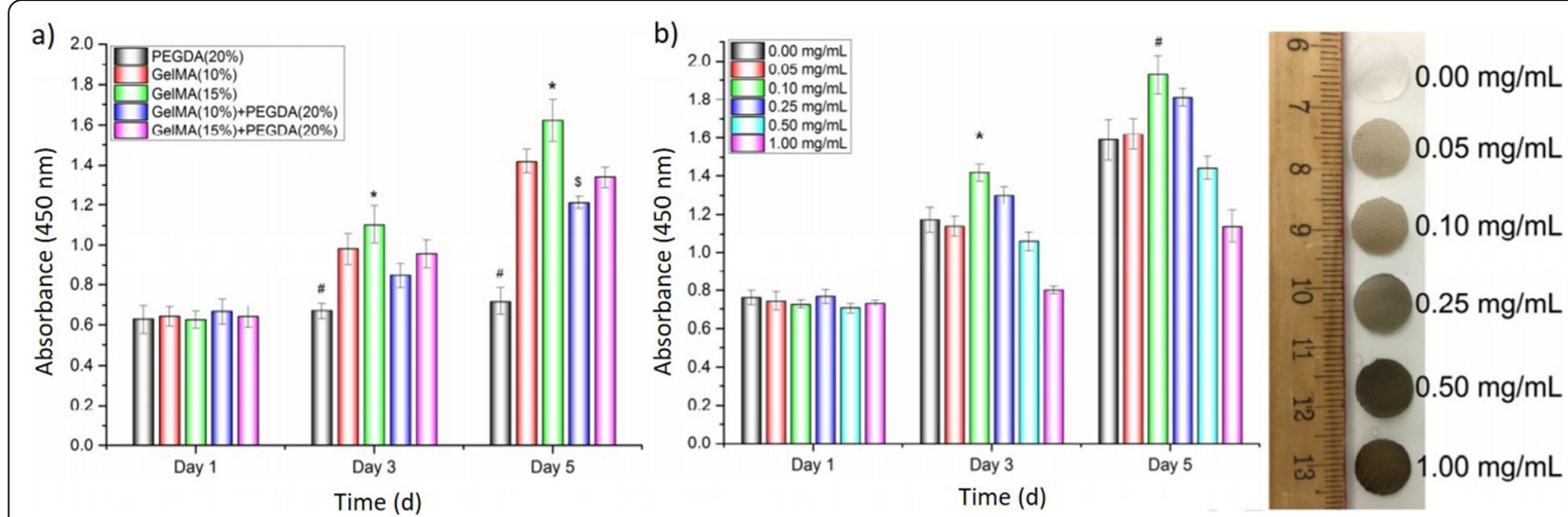

Fig. 11 a Evolution along 5 days of MSCs proliferation on hydrogels with different compositions. b MSCs proliferation on scaffolds with GelMAPEGDA and different concentrations of GO for 5 days. The photographs represent the corresponding scaffolds. Reproduced with permission from [109]

suitable mechanical strength at the relatively low temperature of $-32{ }^{\circ} \mathrm{C}$. It allows the incorporation of a large quantity of biomolecules/drugs into scaffolds and the retention of a high level of the biomolecule's biological activity. It does not require UV light and postsintering use of a high-power laser, avoiding some typical 3D printing's disadvantages. Despite being barely explored, the in situ incorporation of GO-loaded drugs/ biomolecules into scaffolds by this method shows great potential in TE [114]. A recent and novel bioactive PLGA/ $\beta$-tricalcium phosphate $(\beta$-TCP) composite scaffold, in which GO and a bone morphogenetic protein were loaded in situ, was produced by Zhang et al. using the cryogenic 3D printing method [115]. The composites

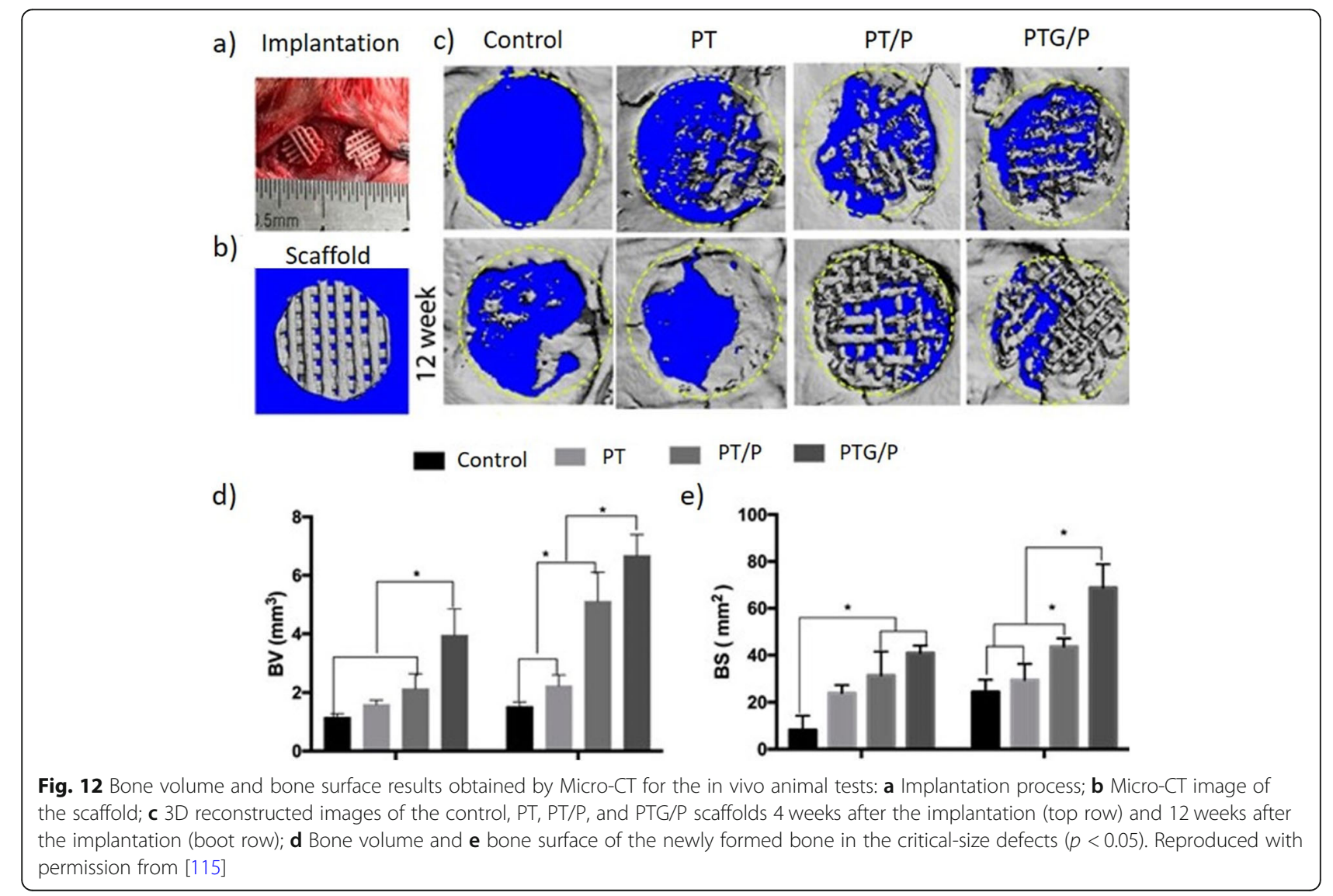


were produced at various GO concentrations $(0,0.025$, 0.05 , and $0.1 \mathrm{wt} . \%$ with respect to the final mixture) and were designated as 'PT/P', '0.025PTG/P', '0.05PTG/P', and '0.1PTG/P', respectively. The PLGA/ $\beta$-TCP scaffold without peptide was generated as the negative control and denoted as 'PT'. Critical-sized calvarial defects were successfully created in rats (Fig. 12). Scaffolds with a diameter of $5 \mathrm{~mm}$ were implanted in these animal models to evaluate in vivo bone regeneration. When the implantation time was extended to 12 weeks, more bone formation was observed in the groups with scaffolds than in the control group, particularly in the graphenebased scaffolds. The bone volume (BV) and bone surface (BS) were quantitatively analyzed to confirm the bone regeneration ability - Fig. 12. The scaffolds presented a customized shape with hierarchical porosity and were mechanically comparable to human cancellous bone. GO improved the scaffold's wettability and mechanical strength as well as tuned the peptide release, promoting bone marrow - derived mesenchymal stem cells ingrowth into the scaffold, enhancing the osteogenic differentiation in a critical bone defect [115].

In summary, several graphene-based composites have been processed by 3D printing to manufacture scaffolds with enhanced biological, mechanical and electrical performance, to regenerate a variety of tissues such as bone, cartilage, or the nervous system. A summary of relevant examples of such scaffolds, as well as their main processing details and properties, is presented in Table 5.

\section{Biosensors}

The incorporation of conductive materials such as graphene derivatives into polymers to form conductive composites allows the printing of electrodes and circuits, which can be integrated into complex structures, permitting the electrochemical detection of organic compounds and biologically active molecules. Graphene-based composites can be combined with biological receptors such as enzymes, antibodies, and single-stranded DNA. Printed graphene-based biosensors have good reliability and great potential for numerous applications [124].

Palenzuela et al. [125] fabricated ring-shaped electrodes by FDM using graphene/PLA composite filaments, for the electrochemical sensing of picric acid and ascorbic acid. The activation of the graphene-based 3Dprinted electrodes consisted of DMF-assisted partial dissolution of the insulating PLA. Different activation times $(1,10,20$, and $60 \mathrm{~min})$ were studied, but immersing the 3D printed electrodes in DMF for 10 min was the optimum time. Picric acid and ascorbic acid could be detected with these electrodes in a wide range of concentrations, from 5 to $350 \mathrm{ppm}$ for the former and 10 to $500 \mu \mathrm{M}$ for the latter [125].
Cardoso et al. [126] used FDM to produce biosensing platforms from graphene-PLA filaments. The enzymatic biosensor was fabricated on the PLA-graphene surface and used for glucose sensing in blood plasma. The biosensor presented a limit of detection (LOD) of $15 \mu \mathrm{M}$ $\mathrm{L}^{-1}$, inter-day, and intra-day precision lower than $5 \%$, and adequate recovery values (90-105\%) for the analysis of plasma. At the same time, after a surface treatment of the 3D-printed sensor, it also exhibited improved electrochemical properties for the direct detection of nitrite and uric acid [126].

Marzo and co-workers [127] developed 3D-printed enzymatic graphene-PLA electrodes to immobilize horseradish peroxidase (HRP) creating a direct electron transfer biosensor for hydrogen peroxide $\left(\mathrm{H}_{2} \mathrm{O}_{2}\right)$ detection. 3D electrodes were first printed by FDM using graphene/PLA filaments and then exposed to a chemical and electrochemical treatment for activation. Electrodes modified with gold nanoparticles enhanced the direct electron transfer between the HRP and the biosensors. Figure 13a depicts the good selectivity to $\mathrm{H}_{2} \mathrm{O}_{2}$ of DMF$\mathrm{EC} / \mathrm{AuNPs} / \mathrm{HRP}$. The response of these biosensors with and without gold nanoparticles (DMF-EC/HRP and DMF-EC/ AuNPs/HRP, respectively) in human serum was also evaluated (Fig. 13b) as well as their long-term stability up to 7 days, in the presence of 25 (Fig. 13c) and $50 \mu \mathrm{M}$ of $\mathrm{H}_{2} \mathrm{O}_{2}$ (Fig. 13d). This work opens possibilities for 3D-printed enzymatic systems to detect other biomarkers without the use of electron mediators and binder polymers [127].

Leigh et al. [128] used a PCL/carbon black (CB) composite filament to manufacture electronic sensors capable of detecting mechanical flexing and capacitance changes, using a low-cost 3D printer. The filler ratio was defined considering the percolation threshold and the melt viscosity of the composite, the final chosen loading of $\mathrm{CB}$ was $15 \mathrm{wt} \%$. Through resistivity tests, the authors verified the existence of a piezoresistive behaviour, enabling its use in the field of biomechanics. The sensors also have a capacitive behaviour when printed as part of an interface device or embedded inside a "smart" vessel, making it possible to detect the presence and quantity of a liquid inside [128].

Lee and co-workers [129] produced PCL/graphene (10 $w t \%)$ electrodes using a KIMM SPS1000 bioplotter extrusion printing system. These electrodes presented robustness, flexibility, biodegradability, and conductivity required for the electrochemical studies. Before the electrochemical experiment, the electrode was immersed in DMF solvent for $10 \mathrm{~min}$ to remove the PCL that blocked the graphene layer, allowing an ideal contact between the graphene and the electrolytes. Biocompatibility was demonstrated by the electrochemical response derived from the diatom 
Table 5 Graphene-based 3D-printed scaffolds

\begin{tabular}{|c|c|c|c|c|c|}
\hline $\begin{array}{l}\text { AM } \\
\text { technique }\end{array}$ & Scaffold & Printing parameters & Cellular behavior & Mechanical properties & Ref \\
\hline \multirow[t]{7}{*}{$\begin{array}{l}\text { Extrusion- } \\
\text { based 3D- } \\
\text { printing }\end{array}$} & $\begin{array}{l}\mathrm{PCL} \\
+ \\
\text { Graphene } \\
(0.13 \text { and } 0.78 \\
\text { wt.\%) } \\
\text { Coating with P1- } \\
\text { latex protein }\end{array}$ & $\begin{array}{l}\text { Pattern:0/90 lay down; } \\
90^{\circ} \mathrm{C} \text {; } \\
\text { slice thickness: } 220 \mu \mathrm{m} ; \\
22 \text { rpm; } \\
\text { speed: } 20 \mathrm{~mm} / \mathrm{s}\end{array}$ & $\begin{array}{l}\text { Human adipose -derived stem cells } \\
\text { (ADSCs) adhered/spread and presented } \\
\text { a spindle-like morphology; osteogenic } \\
\text { differentiation; } \\
\text { Scaffolds(0.78 wt.\%): higher viability/ } \\
\text { spread }\end{array}$ & $\begin{array}{l}\text { Compressive strength } \\
\left(C_{S}\right) \\
C_{s}(0.13 \text { wt.\%): } 80 \mathrm{MPa} ; \\
C_{s}(0.78 \text { wt.\%): } 130 \mathrm{MPa}\end{array}$ & [116] \\
\hline & $\begin{array}{l}\mathrm{PCL} \\
+ \\
\text { Graphene } \\
(0.5 \text { and } 0.78 w t . \%)\end{array}$ & & $\begin{array}{l}\text { ADSCs adhered and proliferated. After } \\
7 \text { and } 14 \text { days, scaffolds with graphene } \\
\text { exhibited better biological performance } \\
\text { over the neat PCL scaffolds. }\end{array}$ & - & [117] \\
\hline & $\begin{array}{l}\mathrm{PCL} \\
+ \\
\text { Modified graphene } \\
\text { nanoplatelets ( } 0.5 \\
\text { wt.\%) }\end{array}$ & $\begin{array}{l}\text { Pattern: } 3 \text { layers arranged in at } \\
90^{\circ} \\
\text { Layers height: } 0.15 \mathrm{~mm} ; 190^{\circ} \mathrm{C} \text {; } \\
\text { Bed: } 50^{\circ} \mathrm{C} ; \\
\text { Speed: } 15 \mathrm{~mm} / \mathrm{s}\end{array}$ & $\begin{array}{l}\text { Adhesion and proliferation of human } \\
\text { chondrocytes; } \\
\text { Higher cell proliferation in 3D scaffold } \\
\text { comparing to polystyrene positive } \\
\text { control; } \\
\text { Graphene did not increase the cellular } \\
\text { toxicity }\end{array}$ & $\begin{array}{l}\text { No mechanical results for } \\
\text { scaffolds } \\
\text { Composite filaments ( } 0.5 \text { wt. } \% \\
\text { graphene): } \\
\text { Young's modulus }=271 \pm 29 \\
\text { MPa } \\
\text { Tensile strength: } 16.35 \pm 0.28\end{array}$ & [118] \\
\hline & $\begin{array}{l}\mathrm{PCL} \\
+ \\
\mathrm{GO} \\
(0.1 \text { and } 0.5 \mathrm{wt} . \%)\end{array}$ & $\begin{array}{l}\text { Cuboidal shape } 22 \text { layers } \\
\text { Layer thickness: } 2.2 \mathrm{~mm} ; \\
100^{\circ} \mathrm{C} ; \\
80-100 \text { PSI; } \\
\text { Speed: } 1 \mathrm{~mm} / \mathrm{s}\end{array}$ & $\begin{array}{l}\text { Murine preosteoblast cells with higher } \\
\text { proliferation and osteogenic } \\
\text { differentiation in scaffolds with } 0.5 \text { wt.\% } \\
\mathrm{GO})\end{array}$ & $\begin{array}{l}C_{S}(P C L): 75.36 \pm 4.07 \mathrm{MPa} \\
\mathrm{C}_{\mathrm{s}}(\mathrm{PCL}+\mathrm{GO}) \text { without any } \\
\text { statistical significance }\end{array}$ & [119] \\
\hline & $\begin{array}{l}\text { Thermoplastic } \\
\text { polyurethane /PLA } \\
+ \\
\text { GO } \\
(0.5,2,5 \text { wt. } \%)\end{array}$ & $\begin{array}{l}\text { Cuboid shape printing in height/ } \\
\text { width direction; } \\
\text { Layer thickness: } 0.1 \mathrm{~mm} \text {; } \\
210^{\circ} \mathrm{C} \text {; } \\
\text { Bed: } 60^{\circ} \mathrm{C} \text {; } \\
\text { Speed: } 20 \mathrm{~mm} / \mathrm{s}\end{array}$ & $\begin{array}{l}\mathrm{NIH} / 3 \mathrm{~T} 3 \text { mouse fibroblast cells with } \\
\text { higher adhesion and proliferation in } \\
\text { scaffolds with } 0.5 w t . \% \mathrm{GO} \text {. }\end{array}$ & $\begin{array}{l}\text { Printing-lying specimen ( } 0.5 \\
\text { wt.\%): Tensile modulus and } \\
\text { yield point increased by } 75.50 \% \\
(\simeq 80 \mathrm{MPa} \text { ) and } 69.17 \% \text {, } \\
\text { respectively. }\end{array}$ & [120] \\
\hline & $\begin{array}{l}\text { Poly (trimethylene } \\
\text { carbonate) (PTMC) } \\
+ \\
\text { Graphene sheets } \\
\text { from rGO } \\
\text { (3 wt.\%) }\end{array}$ & $\begin{array}{l}7 \text { layers; } 1 \times 1 \mathrm{~cm} \\
60-150^{\circ} \mathrm{C} \text {; } \\
\text { nitrogen pressure: } \\
100-200 \mathrm{kPa} \text {; } \\
\text { cross-linking by UV irradiation for } \\
10-15 \text { min }\end{array}$ & $\begin{array}{l}\text { MSCs with good attachment and } \\
\text { viability } \\
\text { Addition of graphene did not alter cell } \\
\text { number; } \\
\text { Electrical stimulation did not } \\
\text { compromise MSCs and the osteogenic } \\
\text { markers were upregulated }\end{array}$ & $\begin{array}{l}\text { Tensile strength: } 7.4 \pm 0.3 \mathrm{MPa} \\
\text { Young's Modulus: } 19.1 \pm 0.5 \\
\mathrm{MPa} \\
\text { Elongation at break: } 420 \pm 11 \%\end{array}$ & [104] \\
\hline & $\begin{array}{l}\text { Chondroitin } \\
\text { sulfate/ALG/ } \\
\text { gelatin+ } \\
\text { GO } \\
\left(1 \mathrm{mg} \mathrm{ml}^{-1}\right)\end{array}$ & 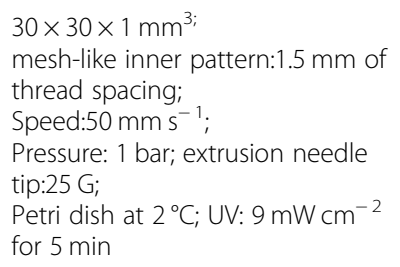 & $\begin{array}{l}\text { hMSCs cells adhered and spread; } \\
\text { Composites presented cells with great } \\
\text { proliferation, alignment and } \\
\text { distribution; } \\
\text { Chondrogenic differentiation }\end{array}$ & $C_{s}: \sim 100 \mathrm{kPa}$ & [121] \\
\hline SLA & $\begin{array}{l}\text { Commercial } \\
\text { polyurethane: } \\
\text { triethylene glycol } \\
\text { dimethacrylate } \\
\text { (TEGDMA) } \\
\text { / PLA-PUA + few- } \\
\text { layer graphene } \\
\text { (0.5 wt.\%) }\end{array}$ & $\begin{array}{l}\text { UV light: } 20 \mathrm{~W} \\
\text { Speed: } \\
0.020 \mathrm{~m}^{-\mathrm{h}^{-1}} \\
\text { XY resolution: } 47 \mu \mathrm{m} \text {, } \\
\text { Z resolution: } 1.25 \mu \mathrm{m} \\
\text { Layer thickness } 0.02 \mathrm{~mm}\end{array}$ & - & $\begin{array}{l}\text { Resin: } \\
\text { Tensile strength: } 68 \mathrm{MPa} \\
\text { Flexural strength: } 115 \mathrm{MPa} \\
\text { Tensile strength: } \\
41.8 \mathrm{MPa} \text { (Direct casting } \\
\text { specimens) } \\
62 \% \text { higher (3D-printed } \\
\text { specimens) }\end{array}$ & [122] \\
\hline SLS & $\begin{array}{l}\text { PVA+ } \\
\text { GO } \\
(2.5 \text { wt.\%) }\end{array}$ & $\begin{array}{l}\text { Laser power: } 5 \mathrm{~W} \text { scan speed: } 400 \\
\text { mm.min }{ }^{-1} \text { spot diameter: } 1.6 \mathrm{~mm} \\
\text { scan spacing/ layer thickness, } 2.7 / \\
0.1-0.2 \mathrm{~mm} \text {, respectively }\end{array}$ & $\begin{array}{l}\text { Human osteoblast like- MG-63 adhered } \\
\text { and spread; } \\
\text { The addition of GO to PVA led to } \\
\text { higher cell growth and proliferation } \\
\text { comparing to pure PVA scaffold. }\end{array}$ & $\begin{array}{l}C_{\mathrm{s}}: 240.49 \mathrm{kPa} \\
\text { Young's Modulus: } 2.47 \mathrm{MPa} \\
\text { Maximum tensile strength: } \\
929.54 \mathrm{kPa} \\
\text { Elongation at break: } 164.6 \%\end{array}$ & [123] \\
\hline
\end{tabular}



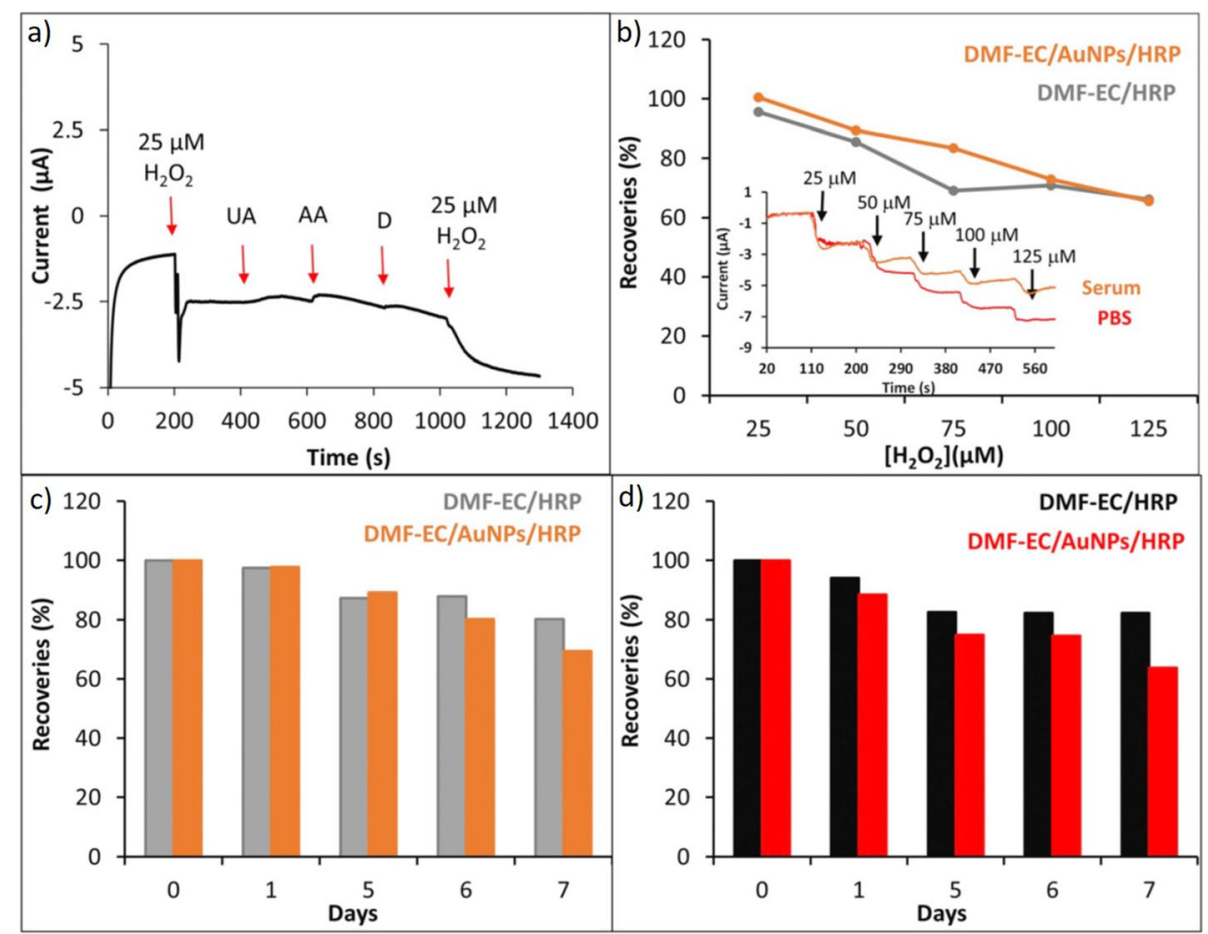

Fig. 13 a Selectivity assay of DMF-EC/AuNPs/HRP for $\mathrm{H}_{2} \mathrm{O}_{2}$ analysis in the presence of $50 \mu \mathrm{M}$ of uric acid (UA), ascorbic acid (AA), and dopamine (D). b Accuracy assay of DMF-EC/AuNPs/HRP and DMF-EC/HRP) for $\mathrm{H}_{2} \mathrm{O}_{2}$ detection. Long-term stability response of 3D DMF-EC/HRP and 3D DMFEC/ AuNPs/HRP biosensors for 25 (c) and 50 (d) $\mu_{M} \mathrm{H}_{2} \mathrm{O}_{2}$ detection. Reproduced with permission from [127]

microalgae grown on the $\mathrm{PCL} /$ graphene substrate. The produced electrode offers a great potential in electrical stimulation to promote tissue formation, as well as in bioelectronic applications [129].

\section{Conclusions}

The manufacture of 3D printed devices is an emerging multidisciplinary field, namely in the biomedical area. In this review, the whole 3D printing process was presented, from the preparation of composites to the most used techniques for printing graphene-based polymer composites for biomedical applications. The properties of the reported graphene-based composite structures have shown significant improvement over polymer matrices without reinforcement, and enhancement of cell response.

3D printing demonstrated the versatility to build complex shapes and custom designed parts, revolutionizing the development of complex structures with target properties, as compared to conventional manufacturing methods. The processing of graphene-based polymer composites with the recent AM technologies has enormous potential for several biomedical applications, namely to engineer distinct tissues such as bone, cartilage, or the nervous system, as demonstrated by the examples discussed in section 3 , and also other tissues such as tendon, ligament, spinal cord or cardiac tissue, which could potentially benefit from the electrical properties conferred by graphene. The development and integration of biosensors is also a growing application of such 3D printed graphene-based nanocomposites, with promising results, as shown in this review.

\section{Abbreviations}

AM: Additive manufacturing; CAD: Computer-aided design; STL: Standard Tessellation Language; FDM: Fused deposition modeling; DIW: Direct ink writing; SLA: Stereolithography; SLS: Selective laser sintering; FFE: Free form extrusion; UV: Ultraviolet radiation; PLA: Polylactic acid; ABS: Acrylonitrile butadiene styrene; PC: Polycarbonate; ALG: Alginate; CHI: Chitosan; DNA: Deoxyribonucleic acid; PCL: Polycaprolactone; PA: Polyamide; GICs: Graphite intercalation compounds; GO: Graphene oxide; rGO: Reduced graphene oxide; EG: Expanded graphite; GNPs: Graphene nanoplatelets; BMSCs: Bone mesenchymal stem cells; PMMA: Polymethylmethacrylate; PVA: Polyvinyl alcohol; PS: Polystyrene; PU: Polyurethane; PET: Polyethylene terephthalate; PE: Polyethylene; PPy: Polypyrrole; DMF: Dimethylformamide; PANI: Polyaniline; PDMS: Polydimethylsiloxane; TE: Tissue engineering;

ES: Electrical stimulation; TNF-a: Tumor necrosis factor alpha; IL-

1B: Interleukin-1 beta; NBR: Natural bone regeneration; PLGA: Polylactide-coglycolide; hMSCs: Human mesenchymal stem cells; GelMA: Gelatinmethacrylate; PEGDA: Poly (ethylene glycol) diacrylate; PEEK: Polyether ether ketone; $\beta$-TCP: $\beta$-tricalcium phosphate; $\mathrm{BV}$ : Bone volume; $\mathrm{BS}$ : Bone surface; ADSCs: Adipose-derived stem cells; Cs: Compressive strength; PTMC: Poly (trimethylene carbonate); TEGDA: Triethylene glycol dimethacrylate; LOD: Limit of detection; HRP: Horseradish peroxidase; DMF-EC/AuNPs/ HRP: 3D electrode with chemical/electrochemical treatment and gold nanoparticles; DMF-EC/HRP: 3D electrode with chemical/electrochemical treatment without gold nanoparticles; UA: Uric acid; AA: Ascorbic acid; D: Dopamine; CB: Carbon black 


\section{Acknowledgements}

IPC acknowledges the support of the Portuguese Foundation for Science and Technology (FCT) through the National Funds Reference UIDB/05256/ 2020 and UIDP/05256/2020. 13Bs acknowledges the support of FCT through the Project SeaJellyBone (PTDC/BTM-MAT/28123/2017). MS acknowledges FCT for the PhD Grant Reference SFRH/BD/138244/2018.

\section{Authors' contributions}

MS and ISP - literature search, manuscript drafting, figure preparation; JAC, MCP and NMA - conceptualization and manuscript revision. All authors read and approved the final manuscript.

\section{Funding}

This work was funded by the Portuguese Foundation for Science and Technology (FCT) through National Funds with Reference UIDB/05256/2020 and UIDP/05256/2020, by FCT and the European program FEDER/FEE through the Project SeaJellyBone (PTDC/BTM-MAT/28123/2017).

\section{Availability of data and materials}

Data sharing is not applicable to this article as no datasets were generated or analysed during the current study.

\section{Declarations}

\section{Competing interests}

The authors declare that they have no competing interests.

\section{Author details}

13B's Research Group, I3Bs - Research Institute on Biomaterials, Biodegradables and Biomimetics University of Minho, Headquarters of the European Institute of Excellence on Tissue Engineering and Regenerative Medicine, AvePark, 4805-017 Barco, Guimarães, Portugal. ' ${ }^{2}$ CVS/3B's PT Associate Laboratory, Braga/Guimarães, Portugal. ${ }^{3}$ Institute for Polymers and Composites, Campus of Azurém, University of Minho, 4804-533 Guimarães, Portugal.

\section{Received: 26 October 2020 Accepted: 4 March 2021}

\section{Published online: 01 April 2021}

\section{References}

1. B. Itapu, A. Jayatissa, A review in graphene/polymer composites. Chem. Sci. Int. J. 23, 1 (2018)

2. S. Hales, E. Tokita, R. Neupane, U. Ghosh, B. Elder, D. Wirthlin, Y.L. Kong, 3D printed nanomaterial-based electronic. Biomed. Bioelectron. Devices Nanotechnol. 31, 172001 (2020)

3. S. Sayyar, D.L. Officer, G.G. Wallace, Fabrication of 3D structures from graphene-based biocomposites. J. Mater. Chem. B 5, 3462 (2017)

4. R. Rajesh, Y. Ravichandran, A. Shanmugharaj, in Advances in Polymer Materials and Technology, ed. by A. Srinivasan, S. Bandyopadhyay. A Hariharasubramanian (CRC Press, Boca Raton, London, New York, 2016), pp. 657-690

5. M. Silva, N.M. Alves, M.C. Paiva, Graphene-polymer Nanocomposites for biomedical applications. Polym. Adv. Technol. 29, 687 (2018)

6. A.M. Pinto, J. Cabral, D.A.P. Tanaka, A.M. Mendes, F.D. Magalhães, Effect of incorporation of graphene oxide and graphene Nanoplatelets on mechanical and gas permeability properties of poly (lactic acid) films. Polym. Int. 62, 33 (2013)

7. C. Valencia, C.H. Valencia, F. Zuluaga, M.E. Valencia, J.H. Mina, C.D. GrandeTovar, Synthesis and application of scaffolds of chitosan-graphene oxide by the freeze-drying method for tissue regeneration. Molecules 23, 2651 (2018)

8. J. Li, X. Liu, J.M. Crook, G.G. Wallace, Development of a porous 3D graphene-PDMS scaffold for improved Osseointegration. Colloids Surf. B Biointerfaces 159, 386 (2017)

9. S. Ghoshal, Polymer/carbon nanotubes (CNT) Nanocomposites processing using additive manufacturing (three-dimensional printing) technique: An overview. Fibers 5, 40 (2017)

10. M. Javaid, A. Haleem, Additive manufacturing applications in medical cases: A literature based review. Alexandria J. Med. 54, 411 (2018)

11. C. Culmone, G. Smit, P. Breedveld, Additive manufacturing of medical instruments: A state-of-the-art review. Addit. Manuf. 27, 461 (2019)
12. R. Donate, M. Monzón, Z. Ortega, L. Wang, V. Ribeiro, D. Pestana, J.M. Oliveira, R.L. Reis, Comparison between calcium carbonate and $\beta$-Tricalcium phosphate as additives of 3D printed scaffolds with Polylactic acid matrix. J. Tissue Eng. Regen. Med. 14, 272 (2020)

13. J. Saroia, Y. Wang, Q. Wei, M. Lei, X. Li, Y. Guo, K. Zhang, A review on 3D printed matrix polymer composites: Its potential and future challenges. Int. J. Adv. Manuf. Technol. 106, 1695 (2020)

14. C.L. Ventola, Medical applications for 3D printing: Current and projected uses. P T 39, 704 (2014)

15. E. Hull, W. Grove, M. Zhang, X. Song, Z.J. Pei, Effects of process variables on extrusion of carbon fiber reinforced ABS filament for additive manufacturing. Manuf. Sci. Eng. 1, 1 (2015)

16. I.B. Dumitrescu, D. Lupuliasa, C.M. Drăgoi, A.C. Nicolae, A. Pop, G. Saramet, D. Drăgănescu, The age of pharmaceutical 3D printing. Technol. Therapeut. Implications Additive Manufact. Farmacia 66, 365 (2018)

17. H. Guo, R. Lv, S. Bai, Recent advances on 3D printing graphene-based composites. Nano Mater. Sci. 1, 101 (2019)

18. J. Liu, C. Yan, in 3D Printing, ed. by D. Cvetković. (IntechOpen, 2018), pp. 137-154. https://doi.org/10.5772/intechopen.74339

19. A. Alafaghani, A. Qattawi, B. Alrawi, A. Guzman, Experimental optimization of fused deposition modelling processing parameters: A design-formanufacturing approach. Procedia Manuf. 10, 791 (2017)

20. S.F. Costa, F.M. Duarte, J.A. Covas, Thermal conditions affecting heat transfer in FDM/FFE: A contribution towards the numerical modelling of the process. Virtual Phys. Prototyp. 10, 35 (2015)

21. D.D. Phan, Z.R. Swain, M.E. Mackay, Rheological and heat transfer effects in fused filament fabrication. J. Rheol. 62, 1097 (2018)

22. S.F. Costa, F.M. Duarte, J.A. Covas, Estimation of filament temperature and adhesion development in fused deposition techniques. J. Mater. Process. Technol. 245, 167 (2017)

23. D. Zhang, B. Chi, B. Li, Z. Gao, Y. Du, J. Guo, J. Wei, Fabrication of highly conductive graphene flexible circuits by 3D printing. Synth. Met. 217, 79 (2016)

24. M Silva, Dissertation, University of Minho, 2016

25. W. Xu, X. Wang, N. Sandler, S. Willför, C. Xu, Three-dimensional printing of wood-derived biopolymers: A review focused on biomedical applications. ACS Sustain. Chem. Eng. 6, 5663 (2018)

26. S. Nara, S. Chameettachal, S. Ghosh, Precise patterning of biopolymers and cells by direct write technique. Mater. Technol. 29, 1 (2014)

27. S. Ghosh, S.T. Parker, X. Wang, D.L. Kaplan, J.A. Lewis, Direct-write assembly of microperiodic silk fibroin scaffolds for tissue engineering applications. Adv. Funct. Mater. 18, 1883 (2008)

28. B. Zhang, S.H. Chung, S. Barker, D. Craig, R.J. Narayan, J. Huang, Direct ink writing of polycaprolactone / polyethylene oxide based 3D constructs. Prog. Nat. Sci. Mater. Int (2020). https://doi.org/10.1016/j.pnsc.2020.10.001.

29. D.G. Karis, R.J. Ono, M. Zhang, A. Vora, D. Storti, M.A. Ganter, A. Nelson, Cross-Linkable multi-stimuli responsive hydrogel inks for direct-write 3D printing. Polym. Chem. 8, 4199 (2017)

30. L. Li, Q. Lin, M. Tang, A.J.E. Duncan, C. Ke, Advanced polymer designs for direct-ink-write 3D printing. Chem. A Eur. J. 25, 10768 (2019)

31. X. Wan, L. Luo, Y. Liu, J. Leng, Direct ink writing based 4D printing of materials and their applications. Adv. Sci. 7, 1 (2020)

32. P. Jiang, C. Yan, Y. Guo, X. Zhang, M. Cai, X. Jia, X. Wang, F. Zhou, Direct ink writing with high-strength and swelling-resistant biocompatible physically Crosslinked hydrogels. Biomater. Sci. 7, 1805 (2019)

33. L. Li, P. Zhang, Z. Zhang, Q. Lin, Y. Wu, A. Cheng, Y. Lin, C.M. Thompson, R.A. Smaldone, C. Ke, Hierarchical co-assembly enhanced direct ink writing. Angew. Chem. Int. Ed. 57, 5105 (2018)

34. B. Román-Manso, F.M. Figueiredo, B. Achiaga, R. Barea, D. Pérez-Coll, A. Morelos-Gómez, M. Terrones, M.I. Osendi, M. Belmonte, P. Miranzo, Electrically functional 3D-Architectured graphene/SiC composites. Carbon 100, 318 (2016)

35. N.W.S. Pinargote, A. Smirnov, N. Peretyagin, A. Seleznev, P. Peretyagin, Direct ink writing technology (3d printing) of graphene-based ceramic Nanocomposites: A review. Nanomaterials 10, 1 (2020)

36. X. You, J. Yang, Q. Feng, K. Huang, H. Zhou, J. Hu, S. Dong, Threedimensional graphene-based materials by direct ink writing method for lightweight application. Int. J. Light. Mater. Manuf. 1, 96 (2018)

37. A.R. Studart, Additive manufacturing of biologically-inspired materials. Chem. Soc. Rev. 45, 359 (2016)

38. S. Singh, S. Ramakrishna, F. Berto, 3D printing of polymer composites: A short review. Mater. Des. Process. Commun. 2, 1 (2020) 
39. X. Wang, M. Jiang, Z. Zhou, J. Gou, D. Hui, 3D printing of polymer matrix composites: A review and prospective. Compos. Part B Eng. 110, 442 (2017)

40. S.Y. Chin, V. Dikshit, B.M. Priyadarshini, Y. Zhang, Powder-based 3D printing for the fabrication of device with micro and Mesoscale features. Micromachines 11, 29 (2020)

41. C.Y. Yap, C.K. Chua, Z.L. Dong, Z.H. Liu, D.Q. Zhang, L.E. Loh, S.L. Sing, Review of selective laser melting: Materials and applications. Appl. Phys. Rev. 2, 041101 (2015)

42. A. Lamikiz, J.A. Sánchez, L.N.L. de Lacalle, J.L. Arana, Laser polishing of parts built up by selective laser sintering. Int. J. Mach. Tool Manuf. 47, 2040 (2007)

43. K. Deshmukh, A. Muzaffar, T. Kovář́k, T. Křenek, M.B. Ahamed, S.K.K. Pasha, in $3 D$ and $4 D$ Printing of Polymer Nanocomposite Materials: Processes, Applications, and Challenges, ed. by K. K. Sadasivuni, K. Deshmukh, M. A. Almaadeed. (Elsevier, Amsterdam, 2020), pp. 527-560

44. J.Z. Gul, M. Sajid, M.M. Rehman, G.U. Siddiqui, I. Shah, K.H. Kim, J.W. Lee, K.H. Choi, 3D printing for soft robotics-a review. Sci. Technol. Adv. Mater. 19 243 (2018)

45. J. Gardan, Additive manufacturing technologies: State of the art and trends. Int. J. Prod. Res. 54, 3118 (2016)

46. P. Ahangar, M.E. Cooke, M.H. Weber, D.H. Rosenzweig, Current biomedical applications of 3D printing and additive manufacturing. Appl. Sci. 9, 1713 (2019)

47. U.K. Sur, Graphene: A rising star on the horizon of materials science. Int. J. Electrochem. 2012, 1 (2012)

48. Y. Zhu, S. Murali, W. Cai, X. Li, J.W. Suk, J.R. Potts, R.S. Ruoff, Graphene and graphene oxide: Synthesis, properties, and applications. Adv. Mater. 22, 3906 (2010)

49. J. Texter, in Graphene Science Handbook: Electrical and Optical Properties, ed. by M. Aliofkhazraei, N. Ali, W. Milne, C. Ozkan, S. Mitura, J. Gervasoni. (CRC Press, Boca Raton, 2016), pp. 315-341

50. E. Beyou, S. Akbar, P. Chaumont, P. Cassagnau, in Syntheses and Applications of Carbon Nanotubes and their Composites, ed. by S. Suzuki. (IntechOpen, 2013), pp. 77-115. https://doi.org/10.5772/50710

51. Y. Hernandez, V. Nicolosi, M. Lotya, F.M. Blighe, Z. Sun, S. De, I.T. McGovern, B. Holland, M. Byrne, Y.K. Gun'ko, J.J. Boland, P. Niraj, G. Duesberg, S. Krishnamurthy, R. Goodhue, J. Hutchison, V. Scardaci, A.C. Ferrari, J.N. Coleman, High-yield production of graphene by liquid-phase exfoliation of graphite. Nat. Nanotechnol. 3, 563 (2008)

52. R. Sengupta, M. Bhattacharya, S. Bandyopadhyay, A.K. Bhowmick, A review on the mechanical and electrical properties of graphite and modified graphite reinforced polymer composites. Prog. Polym. Sci. 36, 638 (2011)

53. W. Du, X. Jiang, L. Zhu, From graphite to graphene: Direct liquid-phase exfoliation of graphite to produce single- and few-layered pristine graphene. J. Mater. Chem. A 1, 10592 (2013)

54. M. Shtein, I. Pri-Bar, M. Varenik, O. Regev, Characterization of grapheneNanoplatelets structure via Thermogravimetry. Anal. Chem. 87, 4076 (2015)

55. P. Cataldi, A. Athanassiou, I.S. Bayer, Graphene Nanoplatelets-based advanced materials and recent Progress in sustainable applications. Appl. Sci. 8, 1438 (2018)

56. A.K. Rasheed, M. Khalid, W. Rashmi, T.C.S.M. Gupta, A. Chan, Graphene based Nanofluids and Nanolubricants - review of recent developments. Renew. Sustain. Energy Rev. 63, 346 (2016)

57. M.R. Safaei, H.R. Goshayeshi, I. Chaer, Solar still efficiency enhancement by using graphene oxide/paraffin Nano-PCM. Energies 12, 1 (2019)

58. B.L. Dasari, J.M. Nouri, D. Brabazon, S. Naher, Graphene and derivatives - Synthesis techniques, properties and their energy applications. Energy 140, 766 (2017)

59. A. Caradonna, C. Badini, E. Padovano, M. Pietroluongo, Electrical and thermal conductivity of epoxy-carbon filler composites processed by calendaring. Materials 12, 1522 (2019)

60. F. Perreault, A. Fonseca, D. Faria, M. Elimelech, Environmental applications of graphene-based nanomaterials. Chem. Soc. Rev. 44, 5861 (2015)

61. G. Yuvaraj, V. Bhuvaneswari, G. Vignesh, L. Vairamuthu, Mechanical Properties of Aluminium Alloy AA2219 Reinforced with Graphite (Paper presented at the First International Conference on Recent Advances in Aerospace Engineering (ICRAAE), Coimbatore, 2017)

62. M.Y. Shen, T.Y. Chang, T.H. Hsieh, Y.L. Li, C.L. Chiang, H. Yang, M.C. Yip, Mechanical properties and tensile fatigue of graphene Nanoplatelets reinforced polymer Nanocomposites. J. Nanomater. 2013, 1 (2013)

63. Z. Zhen, H. Zhu, in Graphene: Fabrication, Characterizations, Properties and Applications, ed. by H. Zhu, Z. Xu, D. Xie, Y. Fang. (Elsevier, Amsterdam 2017), pp. 1-12
64. Y. Zhang, T.R. Nayak, H. Hong, W. Cai, Graphene: A versatile Nanoplatform for biomedical applications. Nanoscale 4, 3833 (2012)

65. A.M. Pinto, I.C. Gonçalves, F.D. Magalhães, Graphene-based materials biocompatibility: A review. Colloids Surf. B Biointerfaces 111, 188 (2013)

66. B. Zhang, Y. Wang, G. Zhai, Biomedical applications of the graphene-based materials. Mater. Sci. Eng. C 61, 953 (2016)

67. Y. Qu, F. He, C. Yu, X. Liang, D. Liang, L. Ma, Q. Zhang, J. Lv, J. Wu, Advances on graphene-based nanomaterials for biomedical applications. Mater. Sci. Eng. C 90, 764 (2018)

68. S. Zhang, K. Yang, L. Feng, Z. Liu, In vitro and in vivo behaviors of dextran functionalized graphene. Carbon 49, 4040 (2011)

69. S. Gurunathan, J.H. Kim, Synthesis, toxicity, biocompatibility, and biomedical applications of graphene and graphene-related materials. Int. J. Nanomedicine 11, 1927 (2016)

70. O. Erol, I. Uyan, M. Hatip, C. Yilmaz, A.B. Tekinay, M.O. Guler, Recent advances in bioactive $1 \mathrm{D}$ and $2 \mathrm{D}$ carbon nanomaterials for biomedical applications. Nanomedicine 14, 2433 (2018)

71. S. Syama, P.V. Mohanan, Comprehensive application of graphene: Emphasis on biomedical concerns. Nano-Micro Lett. 11, 6 (2019)

72. S. Syama, P.V. Mohanan, Safety and biocompatibility of graphene: A new generation nanomaterial for biomedical application. Int. J. Biol. Macromol. $86,546(2016)$

73. C. Wei, Z. Liu, F. Jiang, B. Zeng, M. Huang, D. Yu, Cellular Behaviours of bone marrow-derived mesenchymal stem cells towards pristine graphene oxide Nanosheets. Cell Prolif. 50, 1 (2017)

74. X. Zhang, C. Wei, Y. Li, Y. Li, G. Chen, Y. He, C. Yi, C. Wang, D. Yu, Dosedependent cytotoxicity induced by pristine graphene oxide Nanosheets for potential bone tissue regeneration. J. Biomed. Mater. Res. A 108, 614 (2020)

75. L. Ou, B. Song, H. Liang, J. Liu, X. Feng, B. Deng, T. Sun, L. Shao, Toxicity of graphene-family nanoparticles: A general review of the origins and mechanisms. Part. Fibre Toxicol. 13, 57 (2016)

76. Y.K. Kim, M.H. Kim, D.H. Min, Biocompatible reduced graphene oxide prepared by using dextran as a multifunctional reducing agent. Chem. Commun. 47, 3195 (2011)

77. G.Y. Chen, D.W.P. Pang, S.M. Hwang, H.Y. Tuan, Y.C. Hu, A Graphene-based platform for induced pluripotent stem cells culture and differentiation. Biomaterials 33, 418 (2012)

78. G. Wang, F. Qian, C.W. Saltikov, Y. Jiao, Y. Li, Microbial reduction of graphene oxide by Shewanella. Nano Res. 4, 563 (2011)

79. W. Miao, G. Shim, C.M. Kang, S. Lee, Y.S. Choe, H.G. Choi, Y.K. Oh, Cholesteryl hyaluronic acid-coated, reduced Graphene oxide Nanosheets for anti-cancer drug delivery. Biomaterials 34, 9638 (2013)

80. S. Shi, K. Yang, H. Hong, F. Chen, H.F. Valdovinos, S. Goel, T.E. Barnhart, Z. Liu, W. Cai, V.E.G.F.R. Targeting, Leads to significantly enhanced tumor uptake of Nanographene oxide in vivo. Biomaterials 39, 39 (2015)

81. S. Gurunathan, J.W. Han, V. Eppakayala, A.A. Dayem, D.N. Kwon, J.H. Kim, Biocompatibility effects of biologically synthesized graphene in primary mouse embryonic fibroblast cells. Nanoscale Res. Lett. 8, 1 (2013)

82. Y. Zhang, S.F. Ali, E. Dervishi, Y. Xu, Z. Li, D. Casciano, A.S. Biris, Cytotoxicity effects of graphene and Single-Wall carbon nanotubes in neural Phaeochromocytoma-derived Pc12 cells. ACS Nano 4, 3181 (2010)

83. M.C. Duch, G.R.S. Budinger, Y.T. Liang, S. Soberanes, D. Urich, S.E. Chiarella, L. A. Campochiaro, A. Gonzalez, N.S. Chandel, M.C. Hersam, G.M. Mutlu, Minimizing oxidation and stable nanoscale dispersion improves the biocompatibility of graphene in the lung. Nano Lett. 11, 5201 (2011)

84. B. Li, X.Y. Zhang, J.Z. Yang, Y.J. Zhang, W.X. Li, C.H. Fan, Q. Huang, Influence of polyethylene glycol coating on biodistribution and toxicity of nanoscale graphene oxide in mice after intravenous injection. Int. J. Nanomedicine 9, 4697 (2014)

85. A.F. Rodrigues, L. Newman, D.A. Jasim, I.A. Vacchi, C. Ménard-Moyon, L.E. Crica, A. Bianco, K. Kostarelos, C. Bussy, Immunological impact of graphene oxide sheets in the abdominal cavity is governed by surface reactivity. Arch. Toxicol. 92, 3359 (2018)

86. A. Schinwald, F.A. Murphy, A. Jones, W. MacNee, K. Donaldson, Graphenebased Nanoplatelets: A new risk to the respiratory system as a consequence of their unusual aerodynamic properties. ACS Nano 6, 736 (2012)

87. X. Wang, R. Podila, J.H. Shannahan, A.M. Rao, J.M. Brown, Intravenously delivered graphene Nanosheets and multiwalled carbon nanotubes induce site-specific Th2 inflammatory responses via the IL-33/ST2 Axis. Int. J. Nanomedicine 8, 1733 (2013)

88. J.R. Potts, D.R. Dreyer, C.W. Bielawski, R.S. Ruoff, Graphene-based polymer Nanocomposites. Polymer 52, 1 (2011) 
89. A.V. Rane, K. Kanny, V.K. Abitha, S. Thomas, in Synthesis of Inorganic Nanomaterials, ed. by S. M. Bhagyaraj, O. S. Oluwafemi, N. Kalarikkal, S. Thomas. Methods for synthesis of nanoparticles and fabrication of Nanocomposites (WoodheadPublishing Company, Sawston, 2018), pp. 121-139

90. A. Mirabedini, A. Ang, M. Nikzad, B. Fox, K.T. Lau, N. Hameed, Evolving strategies for producing multiscale Graphene-enhanced fiber-reinforced polymer composites for smart structural applications. Adv. Sci. 1903501 (2020). https://doi.org/10.1002/advs.201903501

91. V. Singh, D. Joung, L. Zhai, S. Das, S.I. Khondaker, S. Seal, Graphene based materials: Past, present and future. Prog. Mater. Sci. 56, 1178 (2011)

92. L. Tang, L. Zhao, in Advanced Composite Materials: Properties and Applications, ed. by E. Bafekrpour. L guan (De Gruyter, Warsaw, 2017), pp. 349-419

93. K. Deshmukh, M.B. Ahamed, R.R. Deshmukh, S.K.K. Pasha, in Biopolymer Composites in Electronics, ed. by K. K. Sadasivuni, D. Ponnamma, J. Kim, J.-J. Cabibihan, M. A. Al Maadeed. PR Bhagat (Elsevier Inc., Amsterdam, 2018), pp. 27-128

94. K. Hu, D.D. Kulkarni, I. Choi, V.V. Tsukruk, Graphene-polymer Nanocomposites for structural and functional applications. Prog. Polym. Sci. 39, 1934 (2014)

95. D. Galpaya, M. Wang, M. Liu, N. Motta, E. Waclawik, C. Yan, Recent advances in fabrication and characterization of graphene-polymer Nanocomposites. Graphene 1, 30 (2012)

96. H. Kim, Y. Miura, C.W. MacOsko, Graphene/polyurethane Nanocomposites for improved gas barrier and electrical conductivity. Chem. Mater. 22, 3441 (2010)

97. J. Wang, Y. Liu, Z. Fan, W. Wang, B. Wang, Z. Guo, Ink-based 3D printing Technologies for Graphene-Based Materials: A review. Adv. Compos. Hybrid Mater. 2, 1 (2019)

98. D.R. Fonseca, R. Sobreiro-Almeida, P.C. Sol, N.M. Neves, Development of non-orthogonal 3D-printed scaffolds to enhance their Osteogenic performance. Biomater. Sci. 6, 1569 (2018)

99. L. Moroni, T. Boland, J.A. Burdick, C. De Maria, B. Derby, G. Forgacs, J. Groll, Q. Li, J. Malda, V.A. Mironov, C. Mota, M. Nakamura, W. Shu, S. Takeuchi, T.B. F. Woodfield, T. Xu, J.J. Yoo, G. Vozzi, Biofabrication: A guide to technology and terminology. Trends Biotechnol. 36, 384 (2018)

100. J.B. Costa, J. Silva-Correia, R.L. Reis, J.M. Oliveira, Recent advances on 3D printing of patient-specific implants for fibrocartilage tissue regeneration. J. 3D Print. Med 2, 129 (2018)

101. B. Costa, J. Park, A.M. Jorgensen, J. Silva-Correia, R.L. Reis, J.M. Oliveira, A. Atala, J.J. Yoo, S.J. Lee, 3D bioprinted highly elastic hybrid constructs for advanced Fibrocartilaginous tissue regeneration. Chem. Mater. (2020). https://doi.org/10.1021/acs.chemmater.0c03556

102. S.J. Hollister, Porous scaffold Design for Tissue Engineering. Nat. Mater. 4, 518 (2006)

103. H. Belaid, S. Nagarajan, C. Teyssier, C. Barou, J. Barés, S. Balme, H. Garay, V. Huon, D. Cornu, V. Cavaillès, M. Bechelany, Development of new biocompatible 3D printed graphene oxide-based scaffolds. Mater. Sci. Eng. C 110, 110595 (2020)

104. S. Sayyar, M. Bjorninen, S. Haimi, S. Miettinen, K. Gilmore, D. Grijpma, G. Wallace, U.V. Cross-Linkable, Graphene/poly (Trimethylene carbonate) composites for 3D printing of electrically conductive scaffolds. ACS Appl. Mater. Interfaces 8, 31916 (2016)

105. E.M. Gonçalves, F.J. Oliveira, R.F. Silva, M.A. Neto, M.H. Fernandes, M. Amaral, M. Vallet-Regí, M. Vila, Three-dimensional printed PCL-hydroxyapatite scaffolds filled with CNTs for bone cell growth stimulation. J. Biomed. Mater. Res. B Appl. Biomater. 104, 1210 (2016)

106. W. Wang, J.R.P. Junior, P.R.L. Nalesso, D. Musson, J. Cornish, F. Mendonça, G. F. Caetano, P. Bártolo, Engineered 3D printed poly(ع-Caprolactone)/ graphene scaffolds for bone tissue engineering. Mater. Sci. Eng. C 100, 759 (2019)

107. A.E. Jakus, E.B. Secor, A.L. Rutz, S.W. Jordan, M.C. Hersam, R.N. Shah, Threedimensional printing of high-content graphene scaffolds for electronic and biomedical applications. ACS Nano 9, 4636 (2015)

108. S. Sayyar, E. Murray, B.C. Thompson, J. Chung, D.L. Officer, S. Gambhir, G.M. Spinks, G.G. Wallace, Processable conducting graphene/chitosan hydrogels for tissue engineering. J. Mater. Chem. B 3, 481 (2015)

109. X. Zhou, M. Nowicki, H. Cui, W. Zhu, X. Fang, S. Miao, S.J. Lee, M. Keidar, L.G. Zhang, 3D bioprinted graphene oxide-incorporated matrix for promoting Chondrogenic differentiation of human bone marrow mesenchymal stem cells. Carbon 116, 615 (2017)
110. P. Feng, J. Jia, S. Peng, W. Yang, S. Bin, C. Shuai, Graphene oxide-driven interfacial coupling in laser 3D printed PEEK/PVA scaffolds for bone regeneration. Virtual Phys. Prototyp. 15, 211 (2020)

111. C. Angulo-Pineda, K. Srirussamee, P. Palma, V.M. Fuenzalida, S.H. Cartmell, H. Palza, Electroactive 3D printed scaffolds based on percolated composites of Polycaprolactone with thermally reduced graphene oxide for antibacterial and tissue engineering applications. Nanomaterials 10, 9 (2020)

112. Y. Zhang, D. Zhai, M. Xu, Q. Yao, H. Zhu, J. Chang, C. Wu, 3D-printed bioceramic scaffolds with antibacterial and Osteogenic activity. Biofabrication 9, 025037 (2017)

113. C.S.D. Cabral, S.P. Miguel, D. de Melo-Diogo, R.O. Louro, I.J. Correia, Green reduced graphene oxide functionalized $3 D$ printed scaffolds for bone tissue regeneration. Carbon 146, 513 (2019)

114. S.T. Bendtsen, S.P. Quinnell, M. Wei, Development of a novel alginatepolyvinyl alcohol-hydroxyapatite hydrogel for 3D bioprinting bone tissue engineered scaffolds. J. Biomed. Mater. Res. A 105, 1457 (2017)

115. Y. Zhang, C. Wang, L. Fu, S. Ye, M. Wang, Y. Zhou, Fabrication and application of novel porous scaffold in situ-loaded graphene oxide and Osteogenic peptide by cryogenic 3D printing for repairing critical-sized bone defect. Molecules 24, 1669 (2019)

116. G.F. Caetano, W. Wang, W.H. Chiang, G. Cooper, C. Diver, J.J. Blaker, M.A. Frade, P. Bártolo, 3D-printed poly( $\epsilon$-Caprolactone)/graphene scaffolds activated with $\mathrm{P} 1$-latex protein for bone regeneration, 3D print. Addit. Manuf. 5, 127 (2018)

117. W. Wang, G. Caetano, W.S. Ambler, J.J. Blaker, M.A. Frade, P. Mandal, C. Diver, P. Bártolo, Enhancing the Hydrophilicity and cell attachment of 3D printed $\mathrm{PCL} /$ graphene scaffolds for bone tissue engineering. Materials (Basel) 9, 992 (2016)

118. I. Rajzer, A. Kurowska, A. Jabłoński, R. Kwiatkowski, W. Piekarczyk, M.B. Hajduga, J. Kopeć, M. Sidzina, E. Menaszek, Scaffolds modified with graphene as future implants for nasal cartilage. J. Mater. Sci. 55, 4030 (2020)

119. J.M. Unagolla, A.C. Jayasuriya, Enhanced cell functions on graphene oxide incorporated 3D printed Polycaprolactone scaffolds. Mater. Sci. Eng. C 102, 1 (2019)

120. Q. Chen, J.D. Mangadlao, J. Wallat, A. De Leon, J.K. Pokorski, R.C. Advincula, 3D printing biocompatible polyurethane/poly (lactic acid)/graphene oxide Nanocomposites: Anisotropic properties. ACS Appl. Mater. Interfaces 9, 4015 (2017)

121. F. Olate-Moya, L. Arens, M. Wilhelm, M.A. Mateos-Timoneda, E. Engel, H. Palza, Chondroinductive alginate-based hydrogels having graphene oxide for 3D printed scaffold fabrication. ACS Appl. Mater. Interfaces 12, 4343 (2020)

122. Z. Feng, Y. Li, L. Hao, Y. Yang, T. Tang, D. Tang, W. Xiong, Graphenereinforced biodegradable resin composites for Stereolithographic 3D printing of bone structure scaffolds. J. Nanomater. 2019, 13 (2019)

123. C. Shuai, P. Feng, C. Gao, X. Shuai, T. Xiao, S. Peng, Graphene oxide reinforced poly (vinyl alcohol): Nanocomposite scaffolds for tissue engineering applications. RSC Adv. 5, 25416 (2015)

124. M. Sharafeldin, A. Jones, J.F. Rusling, 3D-printed biosensor arrays for medical diagnostics. Micromachines 9, 1 (2018)

125. C.L. Manzanares, F.N. Palenzuela, P. Krupička, Z. Sofer, M. Pumera, 3D-printed graphene/Polylactic acid electrodes promise high sensitivity in Electroanalysis. Anal. Chem. 90, 5753 (2018)

126. R.M. Cardoso, P.R.L. Silva, A.P. Lima, D.P. Rocha, T.C. Oliveira, T.M. do Prado, E. L. Fava, O. Fatibello-Filho, E.M. Richter, R.A.A. Muñoz, 3D-printed graphene/ Polylactic acid electrode for bioanalysis: Biosensing of glucose and simultaneous determination of uric acid and nitrite in biological fluids, sensors actuators. B Chem. 307, 127621 (2020)

127. A.M.L. Marzo, C.C. Mayorga-Martinez, M. Pumera, 3D-printed graphene direct electron transfer enzyme biosensors. Biosens. Bioelectron. 151, 111980 (2020)

128. S.J. Leigh, R.J. Bradley, C.P. Purssell, D.R. Billson, D.A. Hutchins, A simple, lowcost conductive composite material for $3 \mathrm{D}$ printing of electronic sensors. PLoS One 7, 1 (2012)

129. K. Kadimisetty, I.M. Mosa, S. Malla, J.E. Satterwhite-Warden, T.M. Kuhns, R.C. Faria, N.H. Lee, J.F. Rusling, 3D-printed Supercapacitor-powered Electrochemiluminescent protein Immunoarray. Biosens. Bioelectron. 77, 188 (2016)

\section{Publisher's Note}

Springer Nature remains neutral with regard to jurisdictional claims in published maps and institutional affiliations. 